\title{
Genetics of Castes and Tribes of India: Indian Population Milieu
}

\author{
M. K. Bhasin \\ Department of Anthropology, University of Delhi, Delhi 110 007, India
}

KEYWORDS Indian; ethnic groups; regional groups; religious groups; occupational groups; linguistic groups

\begin{abstract}
South Asia, constituting mainly the Indian sub-continent, is a panorama of social diversities, racial differences and rich cultural heritage. However many facets of history, race and culture of this area are still relatively unexplored. Debates and doubts centering around the autochthonous status of the early settlers continue - it is very difficult to ascertain how human groups and settlements were formed in the pre-historic times, whether they were the original inhabitants or migrated from some other place and if they migrated, which route did they take. However, the infiltration and admixture of new racial and cultural elements, from time to time, have made the Indian population more diverse and heterogeneous.
\end{abstract}

\section{INTRODUCTION}

Anthropology is the study of man in time and space. The focus of anthropological research is on human population(s) living in an ecological niche.

Anthropology can be categorized under the following main heads:

1. Palaeoanthropology

2. Social/Cultural Anthropology

3. Biological Anthropology

1. Palaeoanthropology: The research and training in Palaeoanthropology is divided in two distinct areas. One emphasizes the methodological training in Prehistoric Archaeology and the other in Palaeontology

Prehistoric Archaeology: The prehistoric archaeology includes a total introduction to the study of geo-chronology through the analysis of such variables as alluvial deposits as also faunal and floral characteristics associated with such deposits on a world-wide basis. Antiquity analysis in terms of the techniques of manufacture as well as their morphology is included as standard components of prehistoric culture. Finally, on the ground of these basics, a thorough study of the various stages of Palaeolithic, Mesolithic, Neolithic and Chalcolithic cultures for the entire Old World is undertaken.

Palaeontology: Palaeontological includes the detailed study of the character and distribution of fossil primates. Primate behaviour

Address of Correspondence: Dr. M. K. Bhasin B-2(GF), South City II, Gurgaon 122 002, Haryana, India with specific attention to adaptational attributes are also included within this scheme. Adaptational radiation in both hominoid and hominid evolution forms another important aspect of this course.

2. Social/Cultural Anthropology: Social/ cultural anthropology is the study of social institutions and human behaviour in a crosscultural perspective. It attempts to unravel the underlying designs of human existence with a view to arrive at generalizations having validity not only at the level of the concerned culture but also at the global level.

3. Biological (Physical) Anthropology: It can be defined as the scientific study of interand intra-population variations.

It was in 1951 that S.L. Washburn laid down a distinction between the pre-1951 and post-1951 physical anthropology referred as Old Physical Anthropology and New Physical Anthropology, respectively. Before 1951 physical anthropology was considered to be a descriptive study of biological parameters to an understanding of their causes. From 1951 onwards mathematical models formulated for population biology have become popular for understanding the causes of variation and co-existence of genetic traits. Thus the orientation of physical anthropology has changed from description to causes to models.

In the descriptive type of physical anthropology, G.W. Lasker has identified five major areas of interest according to which relevant techniques for investigation were devised.

1. The form of bones and teeth

2. Determination of age and sex and ethnic group from bones and teeth 
3. Human growth and development

4. Composition of the body and its variation

5. Body build and its application to human engineering.

Although in Lasker's formulation, dermatoglyphics did not figure, it occupied an important place in physical anthropology preceding 1951. Therefore, for completing the list of the old interests, the inclusion of dermatoglyphics is imperative. Since 1951, the various dermatoglyphic traits occupied an important place in biological anthropology. But it should not be forgotten that these interests listed by Lasker are instrumental in generating a wealth of data, still valuable for accomplishing newer interests. These fields have not been discarded by biological (physical) anthropologists when the New Physical Anthropology, the result of the consanguinity between evolutionary and adaptational theory on the one hand and genetics on the other, had gained ground. With the "New Physical Anthropology", the interests which have come to stay are:

1. Serological studies

2. Biochemical genetics especially of various polymorphic systems.

3. Studies of evolutionary factors such as mutation, natural selection and gene flow.

4. Primatological studies, of their biology and behaviour.

5. Demographic studies, especially of factors that affect inbreeding and genetic drift and the biological consequences of formal kinship and alliance systems.

6. Anthropometric and anthroposcopic studies, with reference to nutritional factors and ensuing demographic characters.

7. Ecological studies dealing with biological and cultural adaptations.

Physical anthropology has achieved new strides after Washburn's 1951 statement. For grasping the laws and processes of human evolution, molecular evidences have been marshalled, leading to the advent of microscopic work in the area. Human cytogenetics has made an outstanding contribution towards the knowledge of adaptation and evolution. Evolution at the genic (elemental) level is that which is being sought through DNA analysis using recombinant techniques. Thus, we have come a long way from morphological studies (morphological, behavioural, anthropometric, and dermatoglyphic traits - the mode of inheritance of all these characters is still rather unclear) to those of genetic or classical markers (blood groups and protein markers), and to the newly discovered molecular techniques which have provided a new direction and a whole battery of powerful polymorphic systems to study genetic diversity (Cavalli-Sforza and Feldman 2003; Jorde and Wooding 2004). The question, what happens to genes with degradation in biotic environment, acquires a primary place. With these newer and still newer interests, different kinds of techniques have been enunciated to understand nature-nurture relationship in a better fashion. Moreover, there has been a concomitant advancement in statistical methods and we are now in a position to make use of many parameters (Collins et al. 2003; Bamshad et al. 2004; Tishkoff and Kidd 2004; Cavalli-Sforza 2005).

The populations of India and other South Asian countries offer great opportunities to study socio-cultural and genetic variability. Perhaps, nowhere in the world people in a small geographic area are distributed as such a large number of ethnic, castes, religious and linguistic groups as in India and other South Asian countries. All these groups are not entirely independent; people belong concurrently to two or more of these groups. People of different groups living side by side for hundreds or even thousands of year try to retain their separate entities by practicing endogamy.

India is a multicultural country. Anthropologists are committed to grasping the dynamics of communities and populations. As anthropology combines the premises of a biological as well as well as socio-cultural study, it looks at the diverse sections of human beings with dual perspective, one derived from its branch called biological anthropology, and the other from social/cultural anthropology. How communities and populations continue to retain their identity, in social and cultural terms on one hand and biological on the other, and how they acquire the characteristics of the others because of cultural borrowing or interbreeding are the questions anthropologists systematically investigate.

India with about 1000 million people has the second largest population in the world and it is one of the world's top twelve megadiversity countries and has vast diversity of human beings, fauna, flora and environmental regimes. Its present population includes stone-age foodgatherers, hunters, fisher-folk, shifting 
cultivators, peasant communities, subsistence agriculturists, nomadic herders, entertainers, as well as those engaged in mechanized and chemicalized agriculture, mechanized fishing, tapping offshore oil and natural gas, running atomic power plants and producing computer software. India has been peopled by human groups carrying a diversity of genes and cultural traits. We have almost all the primary ethnic strains Proto-Australoid, Mediterranean, Mongoloid, Negrito and a number of composite strains. It is homeland of over 4000 Mendelian populations, of which 3700 endogamous groups are structured in the Hindu caste system as 'jatis'. Outside the preview of caste system there are a thousand odd Mendelian populations which are tribal autochthones and religious communities.

Like any other plural society, India offers a cauldron where the processes of unification as well as of fragmentalisation are unceasingly taking place. This presents a situation of cultural, biological and environmental richness and diversity, and one where the constant interactions between communities are aiding the formation of bridges, thus creating a sense of unity. It is in these terms that India offers an ideal case for examining unity in diversity both biological and socio-cultural perspectives. (Bhasin et al. 1994; Lahr and Foley 1998; Bhasin and Walter 2001; Cann 2001; Bamshad et al. 2004).

In the present paper an attempt has been made to give an outline of Indian population milieu.

\section{SKELETAL REMAINS (HOMINOID/HUMAN)}

Earlier it was pointed out that the first real "ancestor" of man is Ramapithecus (name after the Indian god Rama) who lived about 14 million years ago (Fig. 1). Now Ramapithecus is no longer considered a hominid ancestor by palaeontologists. From Central India, Narmada Man skull was found in 1982 by Arun Sonakia (Sonakia 1982). With regard to both its antiquity and phylogenic position, a good deal of controversy is still going on. It is believed by several to be an ante-Neanderthal or Homo erectus (Lumley H and Sonakia 1985; Lumley MA and Sonakia 1985). Kennedy et al. (1991) further identified and concluded on the basis of metric and comparative investigations that "Narmada Man" is appropriately a Homo sapiens. They added, however, that given its broad suite of
Homo sapiens morphometric characters it is not appropriate to assign Narmada man to a new taxon beyond the trinomial designation of Homo sapiens narmadensis. In a more recent publication Kennedy writes: "In the context of current debates about Homo erectus as a valid taxon (is it a species, an evolutionary grade, a paleospecies, or just a collection of specimens certain investigators decide belong together?) and the relationship of middle Pleistocene hominids to anatomically modern sapiens (regional continuity [or multiregional] hypothesis versus the mitochondrial Eve-displacement hypothesis), Narmada has a critical role to play. At present it appears that Narmada is a late middle-pleistocene representative of early Homo sapiens with an impressive suite of anatomical characteristics shared with other early sapiens populations from Eurasia and Africa but possessing certain unique features of cranial morphology that may have evolved in India. It does not seem appropriate to assign Narmada to a new taxon" (Kennedy 2000: p. 180). A number of fossil specimens have been recorded from India, but most of the write-ups totally overlook the aspects of ethnic or racial affinities of the specimens.

An attempt has been made in cataloguing the various skeletal (hominoid/human) remains of India by Kennedy and Caldwell (1984). The research work is mainly confined to the number of specimens, primary dating and archaeological reference and descriptions of burial circumstances and practices apart from giving an account on ageing and sexing. The write-up totally overlooks the aspects of ethnic or racial affinities of the recorded specimens. Earlier, in 1972, Sarkar, who was actively working on the study of the ancient races of India, came out with some ethnic description of the various human skeletal remains. In his earlier work, Ancient Races of Baluchistan, Punjab and Sind (1964), he tried to throw some light on the IndoAryan problem and suggested the builders of Harappa culture as Indo-Caspians. In his later exhaustive work on the Ancient Races of the Deccan, on the basis of examination of human skeletal remains from Langhnaj, Lothal, Nevasa, Chandoli, Hyderabad, Megaliths, Yelleswaram, Piklihal and other sites of the Deccan he postulated that the Dravidian speaking people evolved from the Veddids or Australoids. Even as early as in 1935, Keith also pointed out the evolution of Dravidians from Veddids or 


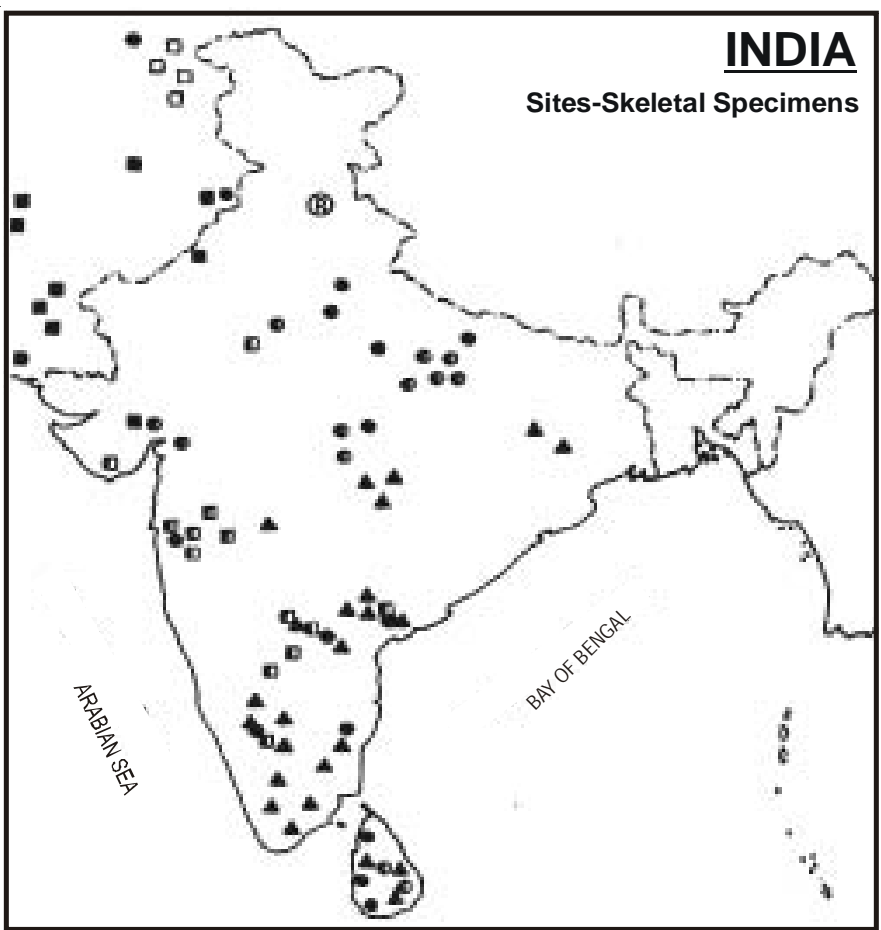

0 Miocene (Ramapithecus) before 14 million years age

- Pleistocene

- Holocene and Later Hunter-Gatherer

- Harappan Civilization

口 Gandharan Grave Culture

Central and Southern Indian Communities

$\Delta$ Megalith Builders and Their Iron Age Collaterals (1300-500 B.C.)

Fig. 1. Prehistoric sites from where skeletal specimens found from India (after Bhasin, Walter, Danker-Hopfe 1994)

Australoids. It is believed that the complexities and variations as one observes in today's population were the results of environmental changes and hybridization. Keith also published (1972) the original reports on skeletal remains from Brahamgiri, where he mentioned of yet another stock: Scytho-Iranian. Other than this, Sastri (1966) also supposed to have come across a fossil pygmy skeleton (although its hominoid status and antiquity is not clear as there were no further references to it). He attributed this to the earliest representative of Negrito in India.

Nevertheless, it remains a fact that there is always the problem of disputes arising while identifying the specimens correctly and hybridization or environmental effects which are often used as alternative causes for marked changes are no longer taken for granted. Moreover, the repeated allegations that most of archaeologists and other investigators seem to be more preoccupied with the artifacts and other material evidences and do not show much interest in the skeletal remains is also mostly true. Therefore, quite a number of studies (may be of the same specimens excavated earlier) are needed today which may come out with a meaningful fossil study of the Indian sub-continent. And it is hoped that when the number of collections of fossils presumed to belong to our ancestral stock would be sufficiently large, it would permit some 
population studies and the specimens can also be used as acceptable population samples.

\section{PREHISTORYANDHISTORY}

\section{Ancient Age}

Both prehistory and history of a country together form the background material towards unfolding the pages of emergence of cultures. The problem of terminology in Indian prehistory is well known. This arises naturaly due to the difficulty in coinciding the Indian prehistoric ages or cultures (which is based on the material evidence or tool types and assemblages) with the European culture items. Many anthropologists/ archaeologists (Cammiade and Burkitt 1930; Subbarao and Allchin 1960; Misra 1961) have attempted to solve this problem but still different terms are in vogue. During the long stone age estimated to cover over 5,00,000 years and forming part of the last geological period namely Pleistocene, and was believed to have been a savage-having no fixed habitation hunting and gathering. It is noted that the great climatic changes of the last glaciation undoubtedly exerted new environmental pressure altering man's number and habitat through changes in the biota stimulating enforced migrations into new environmental niches and changing the lifestyles. Changing in the environment and circumstances gradually brought about changes in tools and artefacts, which are the main, and sometimes the only source to reconstruct the physcial environment, customs, practices and social life of a period. However, with further excavations of other associated materials like mammal bones, ornaments etc. terms like stone age became more or less irrelevant.

Human occupation in the Indian subcontinent began with a series of stone-tool industries (Fig. 2). The stage in man's progress that are then put forward by Sankalia et al. (1973) are:

1. Primitive Food Collecting Stage or Early and Middle Stone Age

2. Advanced Food Collecting Stage or Late Stone Age/Mesolithic

3. Transition to Incipient Food Production or Early Neolithic

4. Settled Village Communities or Advanced Neolithic/Chalcolithic

5. Urbanization or Bronze Age

\section{The Earliest Human Settlements}

The evidence of stone tools in Indian Palaeolithic and certain caves and rockshelters helps only in a very small way to visualize the life of their makers (for the sites see Fig. 2). It is more or less clear that they were ignorant of agriculture and house building and had no domesticated animals. The caves and rockshelters might have served as seasonal camps for human being (?). In the Palaeolithic Age the communities must have been very small and perhaps semi-nomadic.

Piggot (1952) also mentioned that dating is uncertain but earlier man was living in scattered hunting and gathering communities on the alluvial plains and in the marshlands and open parklands of the major river valleys (as suggested by the location and type of tool assemblages).

The epiglacial phase from 10,000 to 50,000 B.C. following the end of pleistocene more or less coincided with the transitional Mesolothic cultural dispersals. Hunting and gathering remained the main sources of making a living but as vegetation shrank and the bigger game gradually disappeared (presumably due to marked climatic changes ) man turned to other sources like water sources, birds or exploitation of plant products as suggested by tool assemblages. But overall, this was a preparatory stage during which man was mostly dependent upon natural resources. In other words, in this period the concentration of population began along river valleys marking the start of a transition to settled living in which food-gathering turned into food-producing. It was argued that the people who camped in rock shelters, the mouths of caves and in open settlement sites could not have numbered more than a couple of hundred individuals.

Kivisild et al. (2000) have studied Indian mitochondrial DNA variants in the global network of maternal lineages and the peopling of the Old World. They summarized their results as follows: "Both western and eastern Eurasian-specific mtDNA haplotypes can be found in India together with strictly Indian-specific ones. However, in India the structure of the haplogroups shared either with western or eastern Eurasian populations is profoundly different. This indicates a local independent development over a very long time period. Minor overlaps with lineages in other Eurasian populations clearly demonstrate that recent immigrations have had 


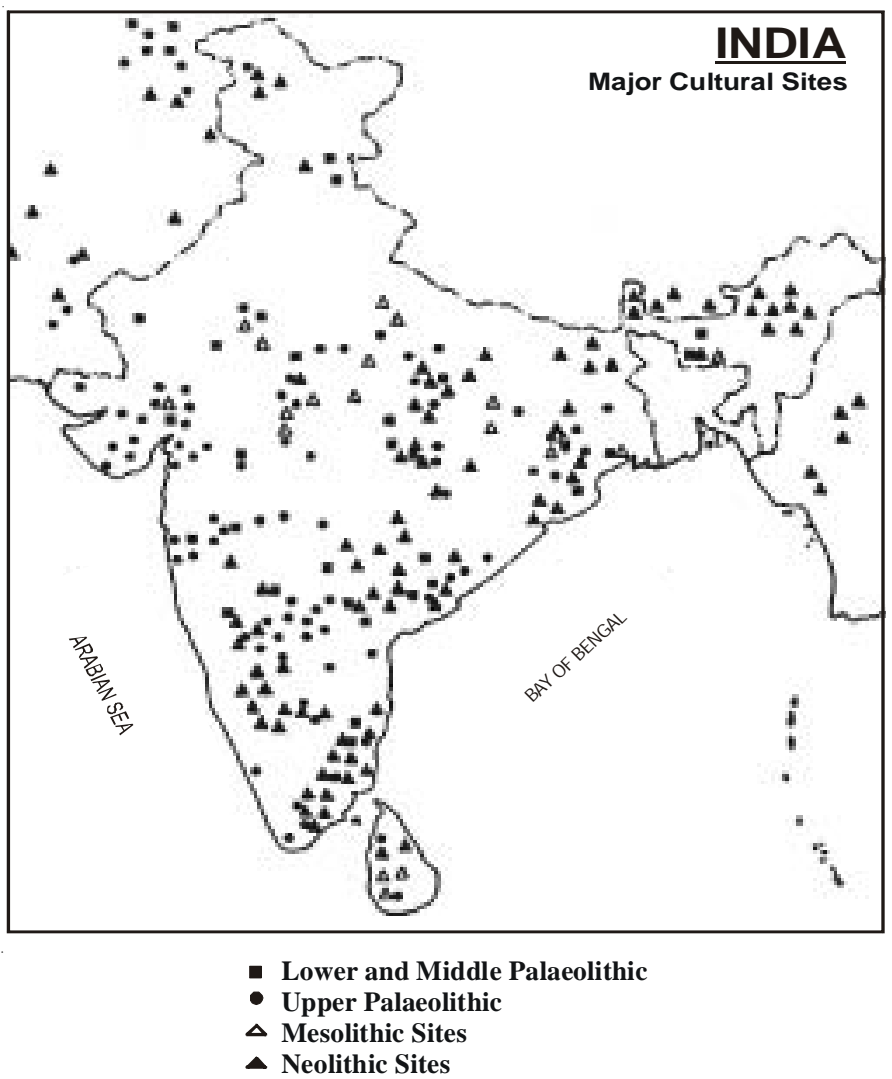

Fig. 2. Major cultural sites found from India (after Bhasin, Walter, Danker-Hopfe 1994)

very little impact on the innate structure of the maternal gene pool of Indians. Despite the variations found within India, these populations stem from a limited number of founder lineages. These lineages were most likely introduced to the Indian subcontinent during the Middle Palaeolithic, before the peopling of Europe and perhaps the Old World in general. Our demographic analysis reveals at least two major expansion phases that have influenced the wide assortment of the Indian mtDNA lineages. The more recent phase, which according to our estimation started around 20,000-30,000 years ago, seems to correspond to the transition from the Middle to the Upper Palaeolithic. The first expansion phase may reflect a demographic burst immediately after the initial peopling of India around 50-60 thousand years ago. This wave of expansion brought forward also those maternal lineages that can rightfully claim the name of Eurasian Eves" (p. 150).
Roychoudhury et al. (2000) reported mitochondrial DNA (mtDNA) profile of 23 ethnic groups of India, which have been drawn from different cultural, linguistic and geographical backgrounds. They observed that Indian populations were founded by a small number of females, possibly arriving on one of the early waves of out-of-Africa migration of modern humans; ethnic differentiation occurred subsequently through demographic expansion and geographic dispersal. Further they have found that South-east Asia was peopled by two waves of migration, one originating in India and the other originating in Southern China.

The Neolithic Age of the Ancient Orient is approximately dated from 6000 to 4000 B.C. The chief characteristics of this period are the exclusive use of non-metal implements, domestication of animals, and a knowledge of agriculture (for the sites see Fig. 2) Corollary to agriculture is the development of village life. 
Towns also started appearing during the Neolithic phase. Towards the end of Neolithic pottery began to appear and metals came into use around 4000 to 3000 B.C.

The full Neolithic which began in different communities between the seventh and sixth millennium B.C. was not characterized by a uniform step-by-step technological sequence from one type of artefact to another or in the presence of types of ceramic ware or even in house types and settlement patterns, rather it was an adjustment of separate small communities to the ecological resources and advantages of local environments.

In other words, the Neolithic does not always imply the universal presence of specified domesticated plants and animals, pottery, polished stone tools and sterotyped settlment patterns. The biological consequences to man were also not the same throughout India.

Bowles (1977) put forth the interpretation that the ability to control production and storage of life's essentials encouraged the growth of larger permanent settlements and these in turn led to technical innovation, division of labour, the formation of social classes and ultimately the superimposition of a system of administrative controls. Biologically such developments meant an increase in the demographic dimensions of alimited number of populations (gene pools) these possessing the knowledge of food production - at the expense of other who retained the earlier type of natural economy and who could not expand numerically beyond the limits set by nature.

As urban centres developed, they attracted a large number of traders, artisans and labourers from ever-increasing distances, a process accentuated during the metal age with the emergence and expansion of Empires and commencement of the historic period about 3000 B.C. After the first population explosion Asia remained, for a millennium or more, the most favoured quarters and thus by the end of this period, Indus valley developed a comparable neolithic nexus.

Permanent settlements of substantial size with populations ranging from a few hundreds to two or three thousands began to emerge at such sites as Brahmagiri, Nevasa, Chandoli, Pandu-Rajar Dhibi (in East Indian Neolithic) etc.

With complexity in society, trade flourished. The development of trade became an important factor in knitting together the social fabric of local communities into village units and regional societies. However it may prove impossible to determine how many clusters there were.

Although a negligible number of hominid remains have been found, it is actually thousands of artefacts from a large number of sites which point to probable contact and migration either west ward or east ward or both during all major periods. Microliths for example, were found concentrated in the western half which seems to imply introduction from that direction.

It has been commented that so much is known about the mesolithic, neolithic and chalcolithic periods of Western Asia than of the southern Peninsula that it is easy to overlook the importance of these areas.

India apparently derived much of its Neolithic as well as its Metal age civilization from two sources-one along the Makran Coast and Baluchistan in the west, the other from southeast Asia by way of the Arakan coast and Assam (Fairservis 1971). The knowledge of the first source is documented from numerous sites in the arid regions along the foothill rim of the Indus valley, the second is still largely covered with dense vegetation and is only beginning to be understood (Bowles 1977).

Until recently, it had been thought that the Indus Valley or Harappan Civilization sites were actually scattered mesolithic hunting and gathering communities transformed into more concentrated permanent Neolithic and CopperBronze Age Settlements. But the discovery of a number of wall-enclosed complex urbanized mound-based Neolithic settlements in the now dried-up Saraswati river bed in Rajasthan in Kathiawar and parts of southern Gujarat have changed this view.

The distinctive features of Harappan Civilization with uniform assemblages of tools, unique methods of water supply, drainage, hypocaust system for heating grand central bath, remarkable individual feature including the ceramic techniques, the systems of weights and measures and the differentiation between the citadel and slave quarters all point to the existence of a complex society with considerable social stratification and complex administrative machinary.

The Indus Valley Civilization extended throughout the entire river basin from the Himalayan foothills and the Doab or Ganges 
watershed to coastal Gujarat with an estnarine dock at Lothal and an outpost at Thane near Bombay.

About the origin of the Harappan Civilization practically nothing definite is known. Different versions are put forward-right from Sumerian or a Semitic origin, to the Dravidian and Mundari are often mentioned. Even origins from Baluchistan and Iranian uplands were suggested ${ }^{1}$.

Sastri and Srinivasachari (1980) proposed that at about 3000 B.C., Baluchistan which as less arid than now was inhabited by small groups of people from the Iranian uplands. These migrants brought with themthe knowledge of agriculture and the organisation of small self-sufficient village communities. In the course of about 500 years, after they had settled in Baluchistan, they migrated in big or small group into the Indus valley.

But the sudden emergence of the urban civilization still baffles the interpreters of Harappan cultures. Some believe that urban civilization was superimposed on the people suddenly by strangers coming from outside at some time in the middle of the $3 \mathrm{rd}$ millennium B.C. It is quite impossible to say when Harappan civilization grew up'. The civilization is unique in a sense that it was almost a fully classified state as early as 3000 B.C. It is said that it may well have been evolved by the natives of the soil and foreign settlers induced new ideas which Harappans absorbed and evolved into a distinct mature culture.

The Indus Valley Civilization has spread from it southern bases to the Himalayan foothills, up the the valley of Kashmir, around 1800 B.C.

The next culture in the chronology which is known as the Chalcolithic is dated roughly from 4000 to 3000 B.C. This is called so because the main tool types representing this culture were made of copper along with stone (for the sites see Fig. 3), although there was no proper Bronze Age in India as in Europe. However, bronze was not unknown and many bronze materials were found. Here, it should be mentioned that there are hundreds of diverse findings which suggest

${ }^{1}$ Excavations at Harappa were resumed in 1986 under the direction of Dr. George F. Dales of the University of California, Berkeley, and are countinuing each year at that site. Some 100 skeletons have been removed from site (Mature Harappan cemetery of R-37) by Drs. Nancy C. Lovell, John R. Lukacs, Brain E. Hemphill and Kenneth A.R. Kennedy. that there are still many problems to be solved.

It is also noted that early Neolithic and Bronze Age migrations into India have not been clearly defined and skeletal evidence from Baluchistan is far from satisfactory.

Sen (1967) argued that leaving aside the questions of ordered sequence of migrations and demographic fluctuations, there was no skeletal evidence to show that a biologically new element could be held accountable for the development of Indus Valley Civilization. Estimations of total population have varied widely and the rationales for the differences climate, food supply, diseases and technology-and their analyses also vary significantly. According to Sarkar (1972), the population of Mohenjodaro and Harappa had been estimated variously between 35,000 and 40,000 with a very high density of population per acre.

It is proved that the valley of Kashmir was known earlier to the settled people and mesolithic artefacts have been found. Excavations in Kashmir also give evidence of earlier proto-urban settlements. Apart from the above, Kashmir also yielded earlier palaeolithic artefacts which are more allied to those of North India, so it might be conjectured that the builders of Burzahom (Kashmir) crossed the Hindukush by 2000 B.C. or thereabouts.

For the rest of Greater India - the scenario is a follows during the ancient age. About the Ganges Basin, the Deccan and the Peninsular and coastal south is far less known but it is assumed that nothing like the civilization developments had taken place at comparable levels of antiquity. It was not until after the entry of the Aryans that the urban civilization extended into the middle Ganges and parts of the Deccan synchronised with the entry of Aryans. The so-called Chalcolithic, Pre-Harappan and Harappan periods in the Indus valley, Gujarat and western Maharashtra are generally contemporary with the so-called Neolithic of the Deccan and Eastern India.

Towards the end of the stone tool phase, the first evidence of agricultural settlement appeared in Baluchistan in the northwest. This culture spread across the northwest corner of the country during the next 2000 years, giving rise eventually to the highly developed Indus Civilization, which came to an abrupt end around 1750 B.C. Whether directly related or not, the decline of the Indus civilization coincided with the movement into India from the Iranian plateau and the Caucasus 
of Aryan peoples speaking an Indo-European language.

\section{Culture Phase and Tools Types}

The contemporary culture phase with the tool types and areas of reign may be a follow:

1. Neolithic - Polished celts, Pottery limited to hand-made jars, in the east (Assam, Bihar, Bengal and parts of the adjacent Deccan).

2. Neolithic-Chalcolithic with polished celts and blade tools, hand-made pottery and wattle and daub houses in Central India, Karnatak, Gujarat, Baluchistan.

3. Chalcolithic-Bronze with Stone blade and copper-bronze tools wheel-made pottery in the north-west (Sind, Saurashtra and Punjab).

4. Chalcolithic-Bronze-with copper or bronze but no stone tools, wheel-made pottery in north-west-Sind, Saurashtra and Punjab.

To sum up, during the second millennium B.C., settlements associated with copper and bronze tools spread rapidly down the Ganges valley. Within a matter of centuries the entire basin had been largely cleared of forests and was supporting a relatively dense population which at least in its biological aspects, is probably reflected in the majority of the present day inhabitants. Meanwhile, it is believed that there was a spread of south-east Asian culture complex and a possible minimal immigration via Assam and Burma into Bengal and Central India.

\section{Main Tools Types}

The terms attributed to different cultures are based on the tool assemblages and types. For example the chalcolithic age has come to be known as an age where the tool assemblages were mainly composed of copper artefacts. Though there are scores of tool assemblages reported and analysed and some are still being excavated-it is impossible to give a description of all these tool types here. Therefore, the following is a simplified and short version of the dominant/main tool types found from the Indian sub-continent (for the sites see Figs. 2 and 3).

A detailed and extensive account on the prehistory and protohistory of Indian subcontinent can be studied from Sankalia (1962, 1979) and Allchin and Allchin (1983).

\begin{tabular}{|c|c|c|}
\hline $\begin{array}{l}\text { Geological } \\
\text { Age } \\
\text { (European) }\end{array}$ & Tool Types & $\begin{array}{l}\text { Culture } \\
\text { Terms }\end{array}$ \\
\hline & Copper & Chalcolithic \\
\hline \multirow[t]{2}{*}{ Holocene } & Polished Celts & Neolithic \\
\hline & Microliths & $\begin{array}{l}\text { Mesolithic } \\
\text { Palaeolithic }\end{array}$ \\
\hline \multirow[t]{5}{*}{ Pleistocene } & Bone Points, Harpoons & Upper \\
\hline & Blades, Burins, Art objects & \\
\hline & Flakes with Levalosians & Middle \\
\hline & Techniques & \\
\hline & Core Bifaces & Lower \\
\hline
\end{tabular}

\section{TheAryans}

The Aryans were initially localized to the west of Indus river, but gradually their influence, observed by the presence of Painted Grey Ware pottery extended further east into the western Ganges valley. Aryan influence also appears to have moved south to the Deccan plateau, indicated by the introduction of iron and later of the Northern Black Polished pottery type (Fig. 4), also associated with Aryan cultural levels in the Ganges valley.

These Aryan penetrations into the Deccan put into contact, by the end of the first millennium B.C., with other types as revealed by the presence of megalithic burial sites, which were widespread in southern Indian by about 300 B.C. Whether the megalithic builders came from outside India or represented a local development is still not clear.

\section{HISTORY}

From the fourth century B.C. onwards for 2000 years, India, particularly in the north, was subjected to repeated waves of penetration by alien peoples. History testifies that Greeks, Parthians, Sakas (Scythians) and Pahlavas including the Kushans were the first to come in after the Indo-Aryan civilization entered its settled course (Fig. 5). The Huns came in somewhat larger numbers at the close of the Gupta epoch. These succession of peoples from outside India were assimilated into Hindu society. On the west coast, Jews and Parsis came after fleeing from their own homelands. Arabian Muslims, Persian Muslims, Turks and Afghans, whose total number was very large came to India from time to time. The Muslim immigration into India began even before the Arab invasions of the Sind quite early in the eighth century A.D. 


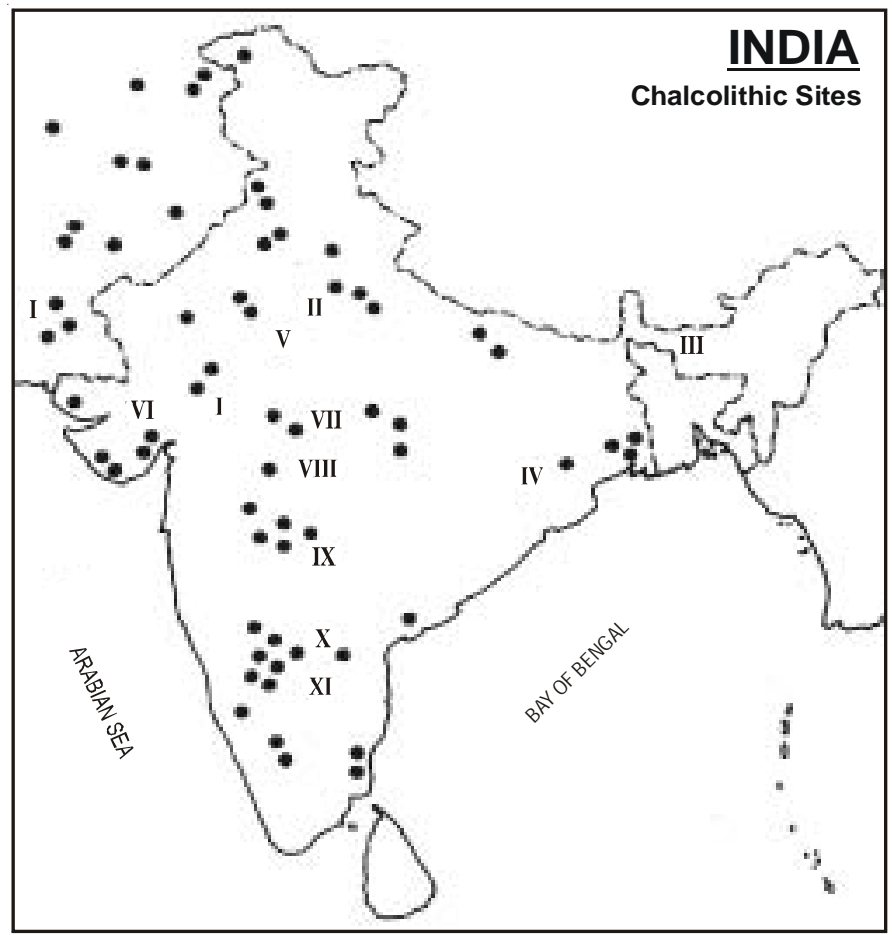

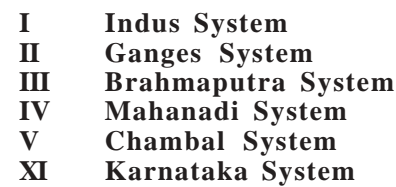

Fig. 3. Major Chalcolithic Cultural sites found from

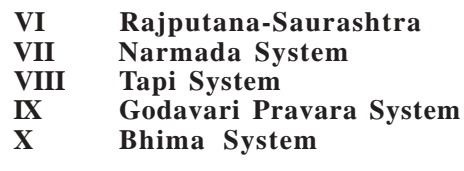

India (after Bhasin, Walter, Danker-Hopfe 1994)

possessing differing characteristic features in their appearance. But one should remember that there are no strict lines of demarcation between races. All these groups blend imperceptibly into one another with intermediate types possessing various combinations of physical characteristics. Modern man is biologically uniform in basic features (for example upright posture, welldeveloped hand and feet, prominent chin, absence of bony eye brow, an intricately struc-tured brain encased in a big skull with a straight high forehead and 46 number of chromosomes) and polymorphous as regards many secondary features. Scientists consider all human beings as belonging to a single species, Homo sapiens. The variations found in groups living in different geographical areas reflect only a differentiation within the single species due to host of biological, social and other factors. In anthropology there
Anthropologists distinguish groups of people on the basis of common origin, living, or having lived, in certain defined regions and

\section{RACIAL CLASSIFICATION}



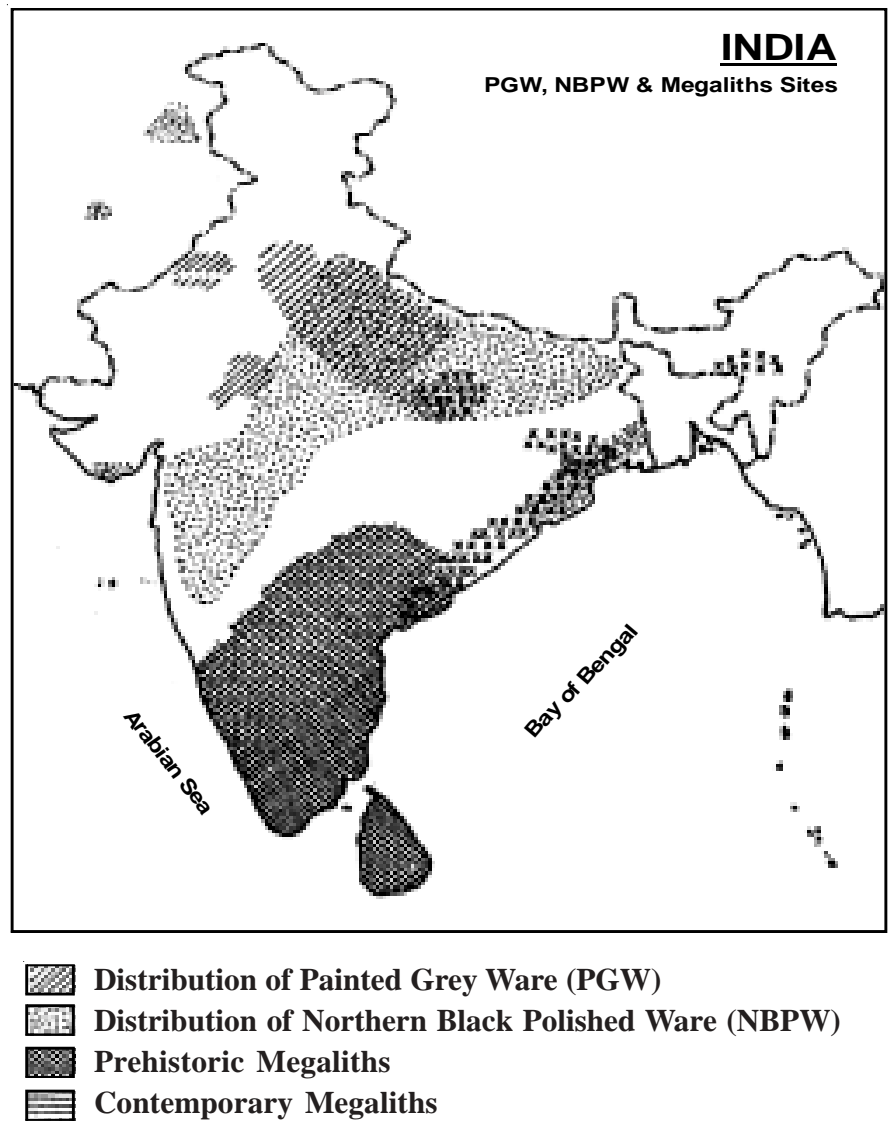

Fig. 4. Distribution of Painted Grey Ware (PGW), Northern Black Polished Ware (NBPW), Prehistoric and Contemporary Megaliths sites from India (after Bhasin, Walter, Danker-Hopfe 1994)

are two schools of thought on the origins of man and the major races-the polycentric and the monocentric schools. The polycentric theory (Franz Weidenreich, U.S.A.) claims that modern man evolved in several regions relatively independent of one another and that peoples developed at different rates. This theory claims that modern man evolved from the "oldest" and "old" people in each region and that this gave rise to the formation of the major racesEuropoid, Negroid, Australoid, Mongoloid, etc. On the other hand monocentrists (for example Henri-Victor Vallois and G. Olivier in France, Francis Howell in the U.S.A., Kenneth Oakley in Britain, Vsevolod P. Yakimov, U.S.S.R.) consider modern man to have evolved in a single region. The ancient Homo sapiens who evolved there did not possess clearly distinguished traits of any of the modern races. It was only when human groups spread geographically and settled in definite territories that racial types evolved. That is why the races of modern mankind resemble one another so closely. This resemblance is a sign of their common origin, of their emergence in a single region. Darwin more than 100 years ago, ventured to predict- that one day it would be found that man had originated in Africa.

Mourant (1983) in his book "Blood Relations" stated that it is almost certain that man evolved from his pre-human ancestors and emerged as a unique tool-making animal somewhere in tropical Africa and that we are therefore, in a sense, all of African origin. Using five polymorphic restriction sites on b gene cluster, Long et al. (1990) worked out, the evolutionary histories and relationships among Africans, Eskimos and Pacific Island populations and reported an African origin for modern Homo sapiens and a phyletic structuring 


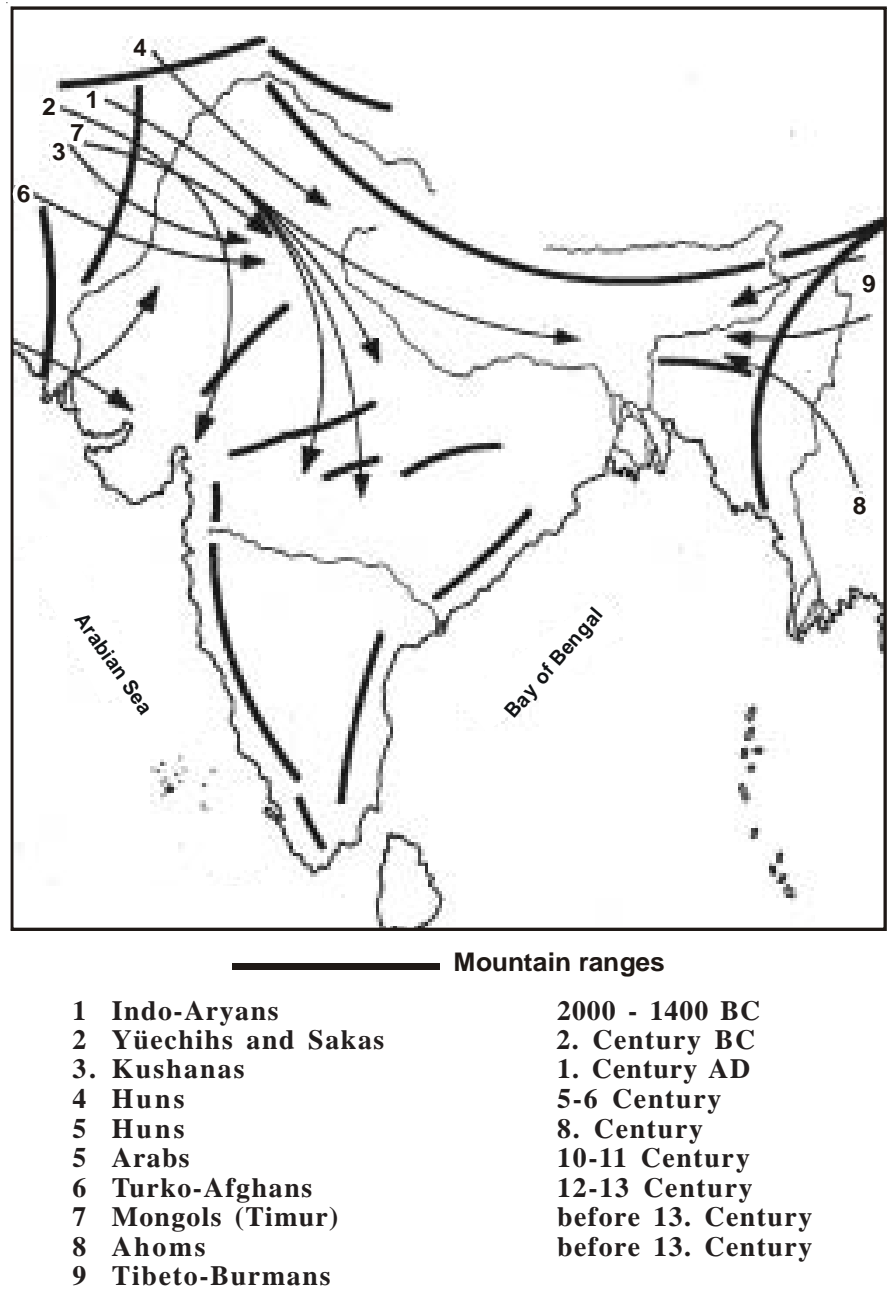

Fig. 5. Waves of penetration by alien peoples (after Walter, Danker-Hopfe, Bhasin 1991)

in the major geographical regions. It is probably rather over a million years ago that man entered Asia from Africa; bones of the early human species, Homo erectus have been found in China as well as in Java, which could have reached only through Asia. Moreover, to reach Europe, which he probably very soon did, he must have passed through south-west Asia. India has served as a major corridor for the dispersal of modern humans out of Africa (Cann 2001; Underhill et al. 2001; Cavalli - Sforza and Feldman 2003; Kivisild et al. 2003; Palanichamy et al. 2004; Cavalli- Sforza 2005). It probably was in Asia that Eurasian man, by now of the modern Homo sapiens species, diverged from African man, and then became differentiated into Caucasoid and Mongoloid types. Another differentiation, which probably took place in Asia, is that of the Australoids, perhaps from a common type before the separation of the Mongoloids. The Caucasiods and the Mongoloids almost certainly became differentiated from one another somewhere in Asia and Caucasoids subsequently spread to the whole western part of the continent and thence to Europe and north Africa (Mourant 1983). The divergence lines among the three major races-Negroid, Caucasoid and Mongoloidestimated by Nei and Roychoudhury (1982) by using a number of genetic markers, reported the divergence between the Negroid and the 
Caucasoid-Mongoloid groups seem to have occurred about $110,000 \pm 34,000$ years ago. On the other hand the divergence between the Caucasoid group and the Mongoloid group seems to have occurred about $41,000 \pm 5,000$ years ago. This corresponds to the time when classic Neanderthals were living. These estimates of divergence lines are much earlier than CavalliSforza and Bodmer's (1971) (20,000-50,000 years ago), but they are not unreasonable in view of the fossil records available (Birdsell 1972).

The Mongoloids are the most numerous of the three major races of mankind and China in the centre of the Mongoloid area has the largest population of these than any country in the world, so the Chinese must be taken as the typical Mongoloids. The ancestors of Japanese passed through Korea to reach Japanese Islands, where they found ancestors of the present Ainu. Through an area to the south of China, extending from the Vietnamese border to the tip of Malaya peninsula, through this there must have passed Homo erectus very long ago on his way to Java ${ }^{1}$ the ancestors of the Australian aborigines. Then came the Indonesians, and finally the Mongoloids in narrower sense, represented by the Mons and the Khmers, the Tibeto-Burmans and the Thais, all of whom probably entered the region before 1000 B.C. (Mourant 1983).

The populations of Siberia are important in supplying evidence regarding the original peopling of the American continent. This took place perhaps about thirty thousand years ago, it was through the Bering Strait which was then dry land owing to the recession of sea level accompanied by last glaciation. Perhaps about thirty thousand years ago, populations of Mongoloid physical type moved into north eastern Siberia and thence into America (Mourant 1983).

The differences between Mongoloids and Caucasoids appear rather sharp as one crosses the mountains in the northern boundary of the Indian sub-continent. The passage from India to Burma is somewhat more gradual, probably because contact here has been present for a long time and some mixing has taken places, whereas

1"Sundashelf, a dry land as the route from Asian mainland to Java is now so well accepted that Shutler and Braches (1987) in their review of the paleoanthropology of Pleistocene island Southeast Asia see it as the route to Java from the Asian mainland for all migrating land mammals" (p. 186) cited from Tumer II (1990). than perhaps (some- forty thousand years ago. the Mongoloids north of the mountains were probably fully differentiated in the Far East before the retreat of the ice allowed them to enter Tibet (Mourant 1983).

In Asia, Australoid if people now live in South of India, the deep ocean between India and Australia means that the direct ancestors of the Australians could not have set out from there. We must picture both India and south-east Asia as being at one time inhabited largely by Australoids who were driven by technologically more advanced people from the north, in the one instance into southern India and Sri Lanka and in other, across Burma and Malaysia and so ultimately through Indonesia and New Guinea to Australia (Mourant 1983).

A number of racial classifications of human populations have been reported in the literature, but there seems to be no agreement about these classifications among anthropologists. However the human populations are broadly divided into three major races: Caucasoid, Negroid and Mongoloid. Many anthropologists have considered two more major groups i.e., Amerind and Australoid or Oceanian (Boyd, 1963). These schemes of classification of human populations were largely based on morphological and anthropometric characters. In the last few decades, however, new methods with elaborate statistics and biometry along with the latest concepts on human genetics have added fresh dimension to the study of human population groups.

To the Indian subcontinent came several waves of immigrants at different periods of history and entered into the ethnic composition of the population at different levels from a very early phase of human civilization. The intrusions of these people with several racial elements have left the strains of various developed races together with their ethnic and cultural substrata in the land, thus representing the elements of all the main divisions of mankind (Fig. 6).

In India the range of somatic variations in different physical traits of its people is remarkably wide. To account for the heterogeneity and to highlight the underlying pattern of the observed variations, earlier European anthropologists, like Charles de Ujfalvy (1881-82) and Captain DrakeBrockman, Sir T.H. Holland (1902) and Waddell (1899) measured groups from various parts of India and attempted various taxonomic classification of the Indian peoples. During the early part of the last century the schemes of classification of Indian 


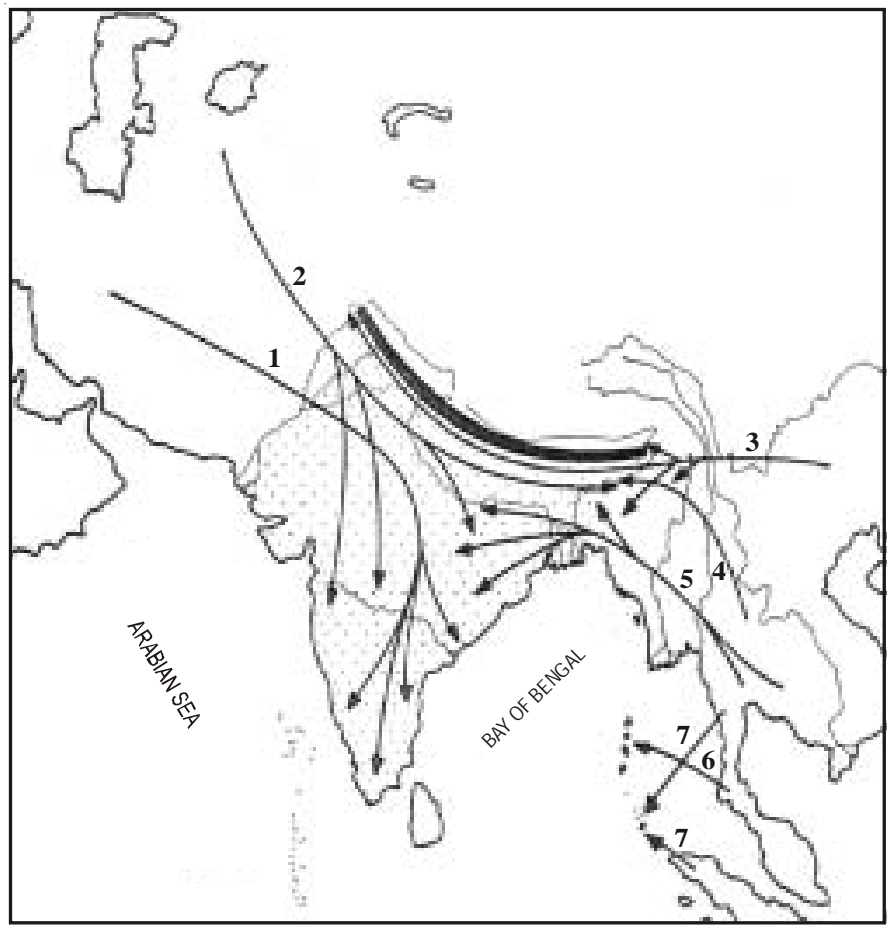

1 Early Caucasoids (Dravidians)

2 Later Caucasoids (Indo-Aryans)

3 Early Mongoloids (Various groups)

4 Later Mongoloids (Ahom)

5 Austro-Asiatics (Various groups)

6 Andamanese

7 Nicobarese

Dots = Original distribution of the autochthonous Indian tribal populations

Fig. 6. Racial migration (after Walter, Danker-Hopfe, Bhasin 1991)

people were largely based on morphological and anthropometric characters. The list of various classifications that have been given on the people of India by different authors is as follows:

1. Risley's Classification (1915)

2. Giuffrida-Ruggari's Classification (1921)

3. Haddon's Classification (1924)

4. v. Eickstedt's Classification $(1934,1952)$

5. Guha's Classification $(1935,1937)$

6. Roy's Classification (1934-38)

7. Sarkar's Classification (1958)

8. Biasutti's Classification (1959)

9. Roginskij and Levin's Classification (1963)

10. Büchi's Classification (1968)

11. Bowles's Classification (1977)

So many classifications on the people of India have been reported and almost all seem to make some sense. An attempt has been made to evaluate the distribution of various racial strains/ elements present in the peoples of India and this is represented in figure 7 (This figure has been drawn while taking into consideration the classifications reported by Guha and others).

\section{Negrito Element}

It is generally admitted that the Negrito represents the oldest surviving type of man and it is possible even that they preceded Neanderthal man by whom, according to Grifth-Taylor, they were displaced and disposed. In any case Negrito seems to have been first inhabitants of South East Asia. The traces of the stock are still to be seen in some of the forest tribes of the higher 


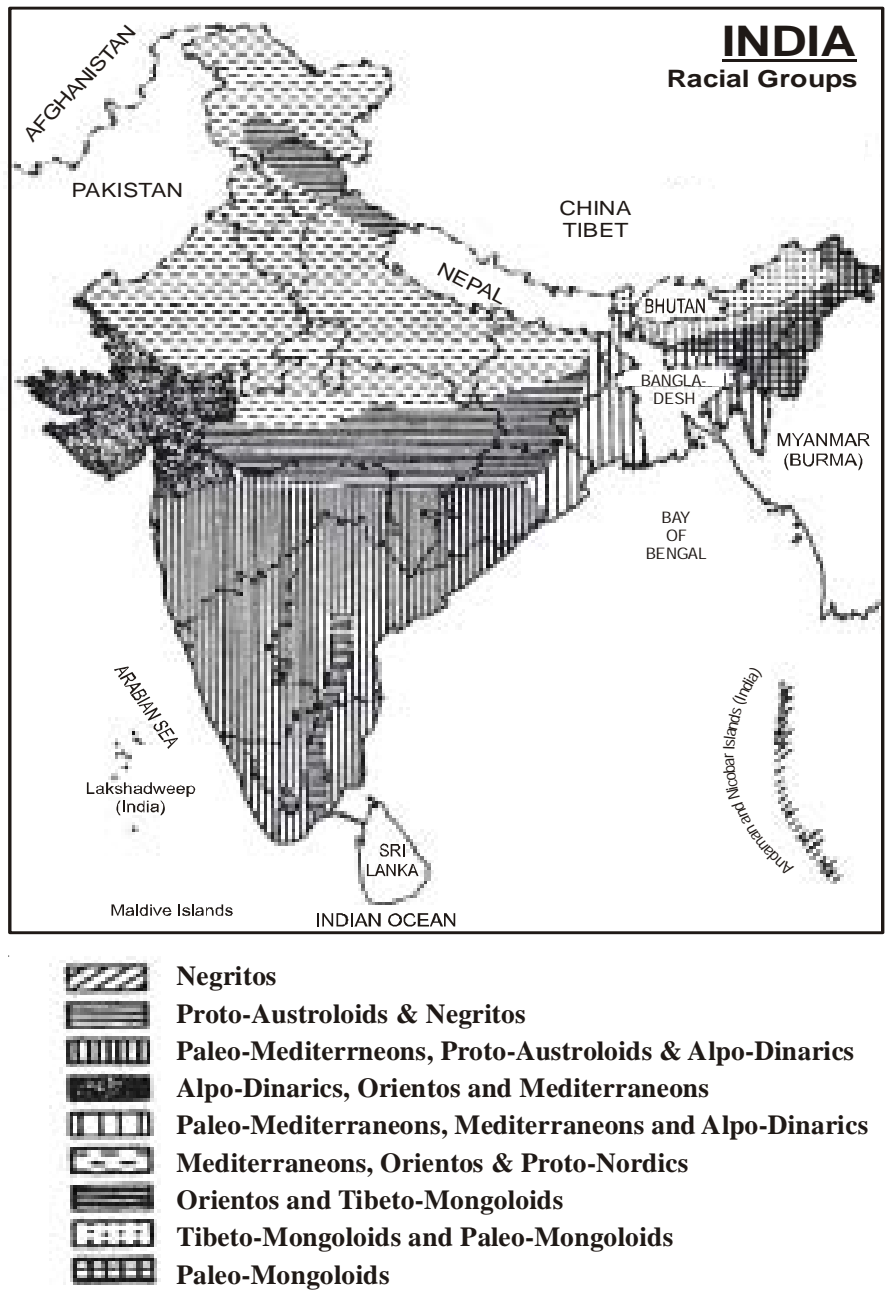

Fig. 7. Distribution of various racial strains present in the people of India (after Bhasin, Walter, Danker-Hopfe 1994)

hills of the extreme south of India and similar traces appear in the inaccessible areas of Assam and Bengal, Burma, where dwarf stature is combined with frizzly hair which appears to have resulted from recent admixture of pure Negrito stock of the Andamans with blood from the main land of India or Burma.

If Negrito was the earliest inhabitants of Southern Asia, they must have been displaced or supplanted by the Proto-Australoid. This dolichocephalic type appears to have its own origin in the west. The view that the Australian is connected with the Neanderthal man, though repeatedly rejected by authorities, seems to die hard since Hrdlicka apparently regards the Neanderthal as having contributed to existing human types, while Sewell appears to revert to the theory of Australian origin and in his account of Mohenjodaro skulls he definitely associates Indian Proto-Australoid type with Australian aborigines on the one hand and with Rhodesian skull on the other.

So many views on the Negrito problem in Indian ethnology have been reported in the literature. Guha $(1928,1929)$ observed the presence of Negrito racial strain from the solitary character of hair form (frizzly type) which he found among the Kadars who live in the interior of the 
chain of hills running from the Anamalais to Travancore. Guha (1961) wrote to Sharma (personal communication) that frizzly type of hair occurs not only among Kadars but among Irulas and the Pulayans also. Guha (1961) disagree with the hypothesis that there had been admixture of African slaves with the Malabar people, giving the reason that if it has occurred in that case it should have been in the coastal areas, where Zamorins of Calicut imported African slaves but not in the interior of the hills 100 miles away. He further added that there is no sign of any African culture among the Kadars. However v. Eickstedt (1939) stated that genuine Negro frizzly hair never has been found in South India. The problem probably arose because the distinguishing words, spiral, woolly or frizzly, have been applied in a vague manner. Sarkar stated that the sporadic cases of frizzly hair may not be Negritoid at all. They may be independent mutations. Whether they are genetically related to Negro or Melanesian frizzly hair group, further genetic researches can disclose.

Banerjee (1959) reported the presence of intermediate or mixed types of hair among the Kadar and accounted its origin as due to admixture with Negroid elements.

Rakshit (1965) suggested that the alleged Negrito Dravidian tribes of south India viz., the Kadar, Irula, Pulayan etc. are in all probability, the foetalized derivatives of Australian basic type.

From the genetic structure of Kadar of Kerala, Saha et al. (1974) evaluated their findings with the other (Sarkar et al. 1959) and observed that there is a little to support that a proportion of Kadar show Negritoid traits. However they added that there is slender evidence which supports the possibility of past African Negro admixture on a small scale. The postulated genetic reconstruction of ancestral Kadar population by them suggested that they may have been similar to Melanesian and Australian aboriginal populations, but their original genetic structure has been modified through incorporating genetic elements not only from Black Africans but from surrounding Dravidian populations.

To study the molecular genetic evidence Mountain et al. (1995) used a small sample of $(n=7)$ of Kadars, without any definite conclusion.

Sarkar (1954) has discussed the Negritos of the Andaman in the light of the process of pygmy formation. Steatopygia, infantlism and dwarfism are probably the effect of endocrine derangements and the reproductive physiology of the Andamanese appears to have been affected as well. The Andamanese appear to have been facing extinction long before they came in contact with civilization. The Andamanese were probably peopled in the quaternary times during a glacial period when the fall of sea-level brought lower Burma in direct contact with the Islands.

Negrito populations occupy parts of the Philippines, Northern Malay peninsula, Andaman Islands and New Guinea have a number of morphological characters similar to those of Pygmies and Bushmen of Africa. Because of this similarity, some anthropologists have hypothesized a common origin of the Negrito populations. However, Nei and Roychoudhury (1982) analysed the genetic relationship and reported that despite some morphological similarity between the Negritos of Southeast Asia and the Pygmies and Bushman of Africa the genetic distance analysis shows them to be genetically different. This result supports Coon's (1965) thesis that the Pygmies and Asian Negritos developed their phenotypic similarity by adapting to similar environmental conditions independently rather than by common descent.

Further Nei and Roychoudhury (1993) suggested a southern route of migration from Africa to Australia in the Pleistocene period to explain the similarities among some populations in Africa, Southeast Asia and Australia and similar observations have also been made by CavalliSforza et al. (1994), Schurr and Wallace (2002).

Murhekar et al. (2001) studied the red cell genetic abnormalities among Great Andamanese and observed that they are the surviving representatives of Negrito populations that were distributed over the entire Southeast Asia in ancient times, which were genetically different from other African populations.

Using mtDNA material, Endicott et al. (2003) and Thangaraj et al. (2003) observed that the Andamanese are more closely related to other Asians than to modern day Africans.

Kashyap et al. (2003) studied the aboriginal groups(Great Andamanese and Jarawas)of Andaman and Nicobar Islands and observed that the distinct genetic identity of the aboriginal populations of the Andaman Islands and other Asian and African populations deciphered by nuclear and mitochondrial DNA diversity suggest that (i) either the aboriginals of Andaman 
are one of the surviving descendents of settlers from an early migration out of Africa who remained in isolation in their habitat in Andaman Islands, or (ii) they are the descendents of one of the founder populations of modern humans.

\section{Proto-Australoid Element}

The earliest stratum of Indian populations was a long-headed, dark skinned, broad nosed people. Their physical features are closely akin to modern aborigines of Chota Nagpur, Central India and the primitive tribes of South India. They are original inhabitants, the so called 'Adi-basis' of India. In the hymns of Rigveda the oldest sacred texts of the Hindus, they are mainly addressed as 'Dasa' (Barbarians) or 'Dasyu' (ugly, sub-human) described as 'Anas' ('a-nas' = noseless or 'an-as' = without a mouth), Krishnagarba (Dark skinned), 'Mridhravak' (Hostile speech) not worshiping Vedic gods with whom Aryan speaking tribes fought during their advent into India from Transcapia.

They have been classified by various authors and so far there has been no agreement on this. Lapicque (1920) was probably responsible for the term Pre-Dravidian. Ruggeri (Chakladar 1921) named it 'Australoid-Veddaic', while Chanda (1916) favoured the term 'Nishada'. v. Eickstedt used the term Weddid for those having closer affinity with the Veddas of Ceylon. Sewell and Guha (1929) in trying to find out the physical affinities of the Nal race, have described Tamils and the Veddas as descendants of the original Proto-Australoid and Proto-Negroid blend. They have also found the Proto-Australoid type occurring among the Mohenjodaro skeletal remains. Hutton (1933) used the term ProtoAustraloid exclusively in his census reports. He even put Veddas under Proto-Australoid. The term Proto-Australoid owes its origin to Dixon (1923). Hooton (1930) introduced changes in Dixon's terminology and replaced term ProtoAustraloid as Pseudo-Australoid while he similarly renamed Proto-Negroid as PseudoNegroid.

The Papuas of New Guinea and the Australian aborigines of Oceania are often called Australoids. Guha (1937) used the term 'ProtoAustraloid' to designate the indigenous people of India presumed to have racial affinities with Australian Aboriginals. It was observed in the morphological traits that there seems to be a regular gradation, the shortest and smallest being the Indian tribes, then come Veddas of Ceylon (Sri Lanka) and lastly the Australians. The Indian tribes retaining the more basic characters and the two extra Indian groups having developed some of the features in a more marked manner. The most appropriate term to apply to them therefore is Proto-Australoid which shows best the genetic relationships between the three. Sarkar (1954) pointed that so long the Australoid is regarded as one of the basic stems of mankind and its prototype is unknown, the use of the term Proto-Australoid seems to be unjustified.

Sanghvi (1976) compared allelic variability observed among tribal populations in India and Australia to study the postulated ancestoral relations between Indian and Australian Aboriginal people. He concluded that the search for appropriate weights for individual alleles to be considered in genetic distance analysis of problems for racial origins has not so far been rewarding.

Simmons (1976) reported on the basis of the blood group genetic data, presently available, that the Veddoids, and other aboriginal peoples of South India relate most closely to the Indian populations, and neither they nor the Veddhas relate in any obvious blood groups genetic makeup to the distant Ainu, or to the even more distant Australian Aboriginals.

Kirk (1976) reported his investigations 15 years ago as he was searching for specific markers which might link Australian Aboriginals with the Veddahs of Ceylon and the "Veddoid" populations of South India and stated that so far no specific markers common to any of these sets of populations have been found. By contrast, the Veddahs of Ceylon do have some genetic markers in common with groups of Southeast Asia, particularly TF CHI and the abnormal haemoglobin $H B^{*} E$. The 'Veddoids' of South India, however, have neither of these markers that possess the abnormal haemoglobin $H B * S$ and having no transferrin variants in the populations which he studied. It is only in the north east of India that transferrin allele $T F * C H I$ is found while $H B^{*} E$ is not uncommon among tribal populations such as Oraons, Konda Reddis and Koya Dora. Roychoudhury (1984) studied genetic relations between Indian Tribes (Toda, Irula, Kurumba of South India); Veddah of Sri Lanka with the Aboriginals of Malay, New Guinea 
and Australia by genetic distance analysis and found the tribes of South India and Sri Lanka genetically closer to each other than to the Aboriginals of Southeast Asia and Oceania. He concluded that despite their morphological similarity there is no genetic evidence to suggest that the Indian tribes and Australian Aboriginals are biologically related.

Pietrusewsky (1990) reported from the craniofacial variation that Australians represent a biologically distinct population, sharing ancestral ties with Melanesians but not with the recent populations of Asia and the rest of the Pacific. The latter represent a second major population complex.

\section{Mongoloid Element}

The Mongoloids are mainly present in the northern and north eastern zones of the Himalayan ranges, valleys and eastern frontiers. Regarding the Mongoloid element, Hutton is of the view, that it may be said to fringe upon the area to Indo-European languages. There is very considerable overlap in the places. In all the overlapping areas the Indo-European languages are definitely intrusive and the Mongoloid element in the population is strong enough to retain its own languages. It is possible that the extension of Mongoloid physical elements has gone a good deal further than the present range of their language would suggest. One of the Mohenjodaro skulls has been identified as definitely Mongoloid and from the lowest stratum of the excavation have been recovered terracotta figurines with unmistakable Mongoloid features having the typical sloping narrow eyes of caricatures of that type.

On the other hand, Eastern Bengal is strongly suggestive of mixed Mongoloid and ProtoAustraloid strain. Buxton suggests that the Pareoean element extends to southern India. Burma, of course, is almost completely Mongoloid and though the existence of other strains is not doubted, they are no longer easy to isolate. There are Proto-Australoid elements too. In some of the hill tribes and on the Assam side a Melanesian strain is to be expected.

Mongolian features have been observed among the tribes of Central and Eastern India, the tribes occupying the such States as Bihar, Orissa, Madhya Pradesh and Andhra Pradesh, in the latter state in areas adjoining Orissa and Madhya Pradesh. The list includes almost important Mundari speaking (Munda Group of Austro-Asiatic Family) tribes like the Munda, Santal, Ho, Juang, Saora, Gadaba etc. and number of Central Indian Dravidian speaking tribes like the Maria, Muria, Kondh, Oraon etc. The occasional presence of Mongolian features among the central and eastern Indian tribal groups foetalized derivative's of Australian types as suggested by Rakshit (1965).

\section{Other Racial Elements}

Amongst the earliest arrivals into Indian subcontinent were long-headed people of PalaeoMediterranean stock, who came in successive waves. They were closely related with the ProtoMediterranean or Proto-Egyptian Brown Race and were long, narrow-headed people, having medium to tall stature, possessed relatively long, narrow faces, low orbit, vertical forehead with protruding occiput and mesorrhine nose. Later waves of this race belonged to the more basic stock of the Mediterranean race. Their skeletal remains have been recovered from the Chalcolithic sites of the Indus Valley (Harappa, 1963, Mohenjo-daro, 1931) etc. and further west from the Aeneolithic sites of Iran and Mesopotamia. They now form a dominant element among the populations of North India and the upper classes.

The next wave was allied to the so-called Oriental Race of Eugen Fischer (1923). They were relatively broad-headed, medium in stature, and broad faced, thus closely related to the brachycephalic Alpine and Armenoid racial type of Europe. Their major concentration was in Asia Minor, Pamirs or the Iranian plateau, from where they are supposed to have infiltrated into India during the third to second millennium B.C.

The early evidence of these elements was found among a few of Chalcolithic crania from Indus Valley sites and later among Iron Age crania from Adittanallur in the Tinnevally District of South India (1963). The origin of the broadheaded strain allied to Alpine and Armenoid lies primarily among the brachycephalic hordes of prehistoric Homo alpinus stock of Central Asia. However, the original source of brachycephaly in Western India appears to have come from Scytho-Iranians who had infiltrated from the ethnic intrusion of the Sakas, Huns, Kushans and Abhiras. Today the stronghold of this type is in Bengal, Rajasthan and Gujarat.

The Dinaric type (mediumly to light 
pigmented, hook nosed, acrocephalic, round heads) finds expression among the population of Bengal and Orissa and got mixed with varying degrees of the Mediterranean element. It is also to be seen in Kathiwar, Kannanda and Tamil areas. The latest great racial movement into India was associated with a long-headed, tall, delicatenosed, fair-skinned people having a long face with well-marked chin, possessing blue eyes more akin to the so-called Nordic Race (pure blond or near blond, long heads) of Europe. During the close of the third or at the beginning of the second millennium B.C. they were supposed to have entered India across the northwestern frontier from the Eurasiatic steppes between southwestern Russia and Siberia. On the basis of linguistic and cultural evidence, they have been described as Indo-European, IndoIranian, or Aryan people, who were ProtoNordics. The area of their civilization was said to be in the Aralo-Caspian Basin.

If the millions of population of India are members of some great branch of humanity, yet strange to say, all or nearly all, who have sought to explain the differentiation of population of India into racial types, have sought the solution of this problem, outside the peninsula. They have never attempted to ascertain how far India has bred her own races. They have proceeded on the assumption that evolution has taken place long ago, far too away but not in India, the great anthropological paradise (Keith 1936). No doubt India has been invaded time and again but it is a fact that 85 per cent of the blood in India is native in the soil. It is necessary that our eyes should be more directly focussed on the possibility of India being an evolutionary field both now and in former times.

Abe and Tamura (1983) and Abe (1985) used multivariate analysis to classify the people of India (South) and Sri Lanka. On the basis of morphological types, Malhotra (1978) stated that Negrito, Australoids, Mongoloids and Caucasoids have contributed to the biological composition of the people of India.

Mourant (1983) classified the peoples of the Indian region broadly into three zones - tribal peoples of Australoid type, living in pockets chiefly in the south, the Caucasoids of slender type and with rather dark skin mostly speaking Dravidian languages occupying the main southern part of the region and more robust Caucasoids, with paler skins and speaking Indo-
European languages, in the north.The people of the Himalayan regions, are partly or wholly Mongoloid (Mourant 1983).

In India the range of somatic variations in different physical traits of its people is remarkably wide. On the basis of these variations a number of European and Indian anthropologists attempted various taxonomic classifications of the Indian peoples. Among Indians all the major racial elements namely Caucasoid, Mongoloid, Australoid and Negritos have been reported. In general, all the classifications given by different authors agree that Himalayan mountain complex region populations have Caucasoid (Aryan and/ or Dravidian) and Mongoloid racial elements in Western and Central Himalayan region and Australoid (Pre-Dravidian), Caucasoid (Aryan and/or Dravidian) and Mongoloid racial elements in Eastern Himalayan region. Whereas in IndusGanga-Brahmaputra plains region, the people from north are having predominantly CaucasoidAryan and Caucasoid-Dravidian racial elements and towards western side Caucasoid (Aryans, Dravidians) and Australoid (Pre-Dravidian) racial elements whereas towards East India, from West Bengal, the racial elements present are similar to that observed among peoples from Eastern Himalayan region, albeit Mongoloid racial element is present in lesser degree. Among populations from Orissa and Bihar the Caucasoid (Aryan and Dravidian) and Australoid (PreDravidian) racial elements are present. Among Central India populations the picture is similar to that observed from Bihar and Orissa. Towards South India the major racial elements are Caucasoid (Dravidian) and Australoid (PreDravidian), whereas among Andamanese, Negrito-like traits are present and in Nicobarese, Mongoloid affinities are observed.

In general, the Australoid (Pre-Dravidian) racial element is predominant among scheduled tribes, whereas among scheduled castes also Australoid racial element is present, but it varies in degree among regions/zones and as scheduled caste populations are having admixture with Caucasoids (Aryan and/or Dravidian) in varying degrees. Mongoloid racial element, which is predominant among populations inhabiting Eastern Himalayan region is also observed among peoples living in inner areas of Western and Central Himalayan regions.

Apart from this, some more populations with different racial elements entered India and were 
assimilated into the local people. The Australoid (Pre-Dravidian) are supposed to be the original inhabitants of India, while the rest are considered to have come in successive waves of immigration of known and sometimes unknown antiquity.

The various classifications given above were initially based on geographical regions, linguistic families, caste group and/or religious groups and were followed by scientifically oriented somatometry and somatoscopy. Finally few genetic markers, like blood groups, were also taken into account. The picture thus emerged was complicated and uncomprehensive as India from the fourth century B.C. for 2000 years, particularly in north received wave after wave of immigrants [(Indo-Aryans, Greeks, Parthians and Sakas (Scythians), Kushans, Huns, Arabs, TurkoAfghans, Mongols (from north and north west directions), Shan (from eastern side)] from different directions and thus took on the character of a miniature museum of races commingling in all sorts of permutation and combinations.

From the section of Indian population milieu of this chapter it may be evaluated that migration from different places formed the Caucasoid (Dravidian, Aryan) and Mongoloid components of India's populations, whereas the original inhabitants who have been classified as Negrito and/or Proto-Australoids may be referred as Nishada (Pre-Dravidians). It is worthwhile to mention here that the racial classifications are currently only of academic interest and are seldom used for categorizing populations, as the population composition at any time is influenced by mating patterns, migrations, genetic drift, mutation and selection under different environments. It should not be forgotten that racial categories are artificial constructs, which have not been able to withstand the test of time. Populations have always intermixed, with the consequence that the pure type ('race') was nothing but a figment of imagination. I dissociate myself from the old race concepts.

\section{IDENTIFY AND DISTINGUISH THE PEOPLE}

For the study of the people of India, researchers have generally used the following criteria to identify and distinguish the people: 1 . Regional Groups, 2. Ethnic Groups, 3. Linguistic Groups, and 4. Religious Groups (Bhasin 1988; Bhasin et al. 1992, 1994)
It should, however, be kept in mind that these are the convenient units of study, although there are significant levels of overlapping between them. For example, an occupational group pursuing traditional job inhabits a region, shares religion with other categories, belongs to one or the other language group and has an aggregation of ethnic properties (Bhasin, 1988).

In the present study an attempt has been made to analyse the above mentioned biogenetical traits into 1. Regional Groups, 2. Ethnic Groups, 3. Traditional Occupational Groups and 4. Linguistic Groups. (after Bhasin 1988; Bhasin et al. 1992, 1994)

\section{Regional Groups}

These can be divided into the following groups:

1. Natural Regions of India

2. Climatological Factors and Climatic Regions of India

3. Political Division of India

Each region has its own characteristics and a brief description of each one will give an idea of what it constitutes of.

\subsection{Natural Regions of India}

The natural regions have broad uniformity in their characteristics, such as relief, geomorphological history, drainage, climate, soil, natural vegetation and wild life. Broadly speaking the Indian sub-continent may be divided in the following natural regions:

1. The Himalayan Mountain Complex

2. The Indus-Ganga-Brahmaputra Plain

3. The Peninsular Plateau and

4. The Islands

\subsection{Climatological Factors and Climatic Regions of India}

Various climatological factors (Rainfall, Humidity, Temperature) and Altitude have been considered to study correlations with different biological traits. The values for the climatological factors are after "Climatological Tables of Observations in 1931-1960" Meteorological Department, Government of India, New Delhi.

A climatic region generally possesses a broad uniformity in climatic conditions produced by combined effects of climatic factors. India can be divided into the following climatic regions after 
Köppen's method, based on the monthly values of temperature and precipitation:

(1) Tropical Savannah Type, (2) Monsoon Type with Short Dry Season, (3) Monsoon Type with Dry Season in High Sun Period, (4) Semiarid and Steppe Climate, (5) Hot Desert Type, (6) Monsoon Type with Dry Winters, (7) Cold Humid Winters Type with Shorter Summer, and (8) Polar Type.

\subsection{Political Division of India}

India is a Union of States. Comprising 29 States and 6 Union Territories, according to the Census 1991, there are 4689 towns and 587,226 inhabited and 47,095 uninhabited villages in the country. The country had 466 districts in 1991.

India-Political and Ethnic Zones: The 29 States and 6 Union Territories (U.T.) have been categorised as follows (after Bhasin 1988):

I. North India, II. West India, III. East India, IV. Central India, V. South India, and VI. Islands (Fig. 8). Himalayan Region may be divided into three divisions, i.e., A) Western Himalaya, B) Central Himalaya, and C) Eastern Himalaya as follows:

I. North India:

(A) Western Himalaya (S. No. 1, 2) and (B) Central Himalaya (S.No. 8):

(1) Jammu and Kashmir, (2) Himachal Pradesh, (3) Punjab, (4) Chandigarh (U.T.), (5) Haryana,

(6) Delhi , (7) Uttar Pradesh, (8) Uttaranchal, and

(9) Rajasthan

II. West India:

(1) Gujarat, (2) Maharashtra, (3) Goa, (4) Daman and Diu (U.T.) and (5) Dadra and Nagar Haveli (U.T.)

III. East India:

C) Eastern Himalaya: (S. No.1 to 8 and Darjeeling District of West Bengal)

(1) Arunachal Pradesh, (2) Assam, (3) Nagaland, (4) Manipur, (5) Mizoram, (6) Tripura, (7) Meghalaya, (8) Sikkim, (9) West Bengal, (10)

Bihar, (11) Jharkhand and (12) Orissa

IV. Central India:

(1) Madhya Pradesh (2) Chhatisgarh

V. South India:

(1) Karnataka, (2) Andhra Pradesh, (3) Tamil Nadu, (4) Kerala and (5) Pondicherry (U.T.).

VI. Islands:

(1) Lakshadweep (U.T.) and (2) Andaman and Nicobar Islands (U.T.).

\section{Ethnic Groups}

The aggregation of biological and sociocultural characteristics constitutes an ethnic group. Within the category of Ethnic Group, we include Castes, Scheduled Castes, Scheduled Tribes and Communities (for details see Ghurye 1969; Hutton 1981). Biological Anthropological studies of such ethnic groups as well as "Communities" have been reported in India. Community is generally referred to a group of people who may have occupational, linguistic, religious or regional characteristics (Bhasin et al. 1992, 1994; Bhasin and Walter 2001).

\subsection{Castes}

The Indian society is highly stratified and is divided into castes, scheduled castes, scheduled tribes etc. It should be understood at the outset that our intention is not to give the detailed account of individual castes, their ceremonies, and their machinery for regulating their relation with other castes, nor of their own internal conduct, but to examine caste in terms of Mendelian population groups.

Hindu caste system is a highly complex institution, though social institutions resembling caste in one respect or another are not difficult to find elsewhere, but caste as we know it in India, is an exclusively Indian phenomenon. The word 'caste' comes from the Portuguese word 'casta', signifying breed, race or kind. Risley (1915) defines it as "a collection of families or groups of families bearing a common name; claiming a common descent from a mythical ancestor, human or divine; professing to follow the same hereditary calling; and regarded by those who are competent to give an opinion as forming a single homogeneous community' is generally associated with a specific occupation and that a caste is invariably endogamous, but is further divided as a rule, into a smaller of smaller circles each of which is endogamous (this is called Jati), so that a Brahman is not only restricted to marrying another Brahman, but to marrying a women of the same subdivision of Brahmans." The internal exogamous division of the endogamous caste is 'Gotra'. There are several stages of groups and the word 'caste' is applied to groups at any stage. The word 'caste' and 'sub-caste' are not absolute but comparative in significance. The larger group will be called a 


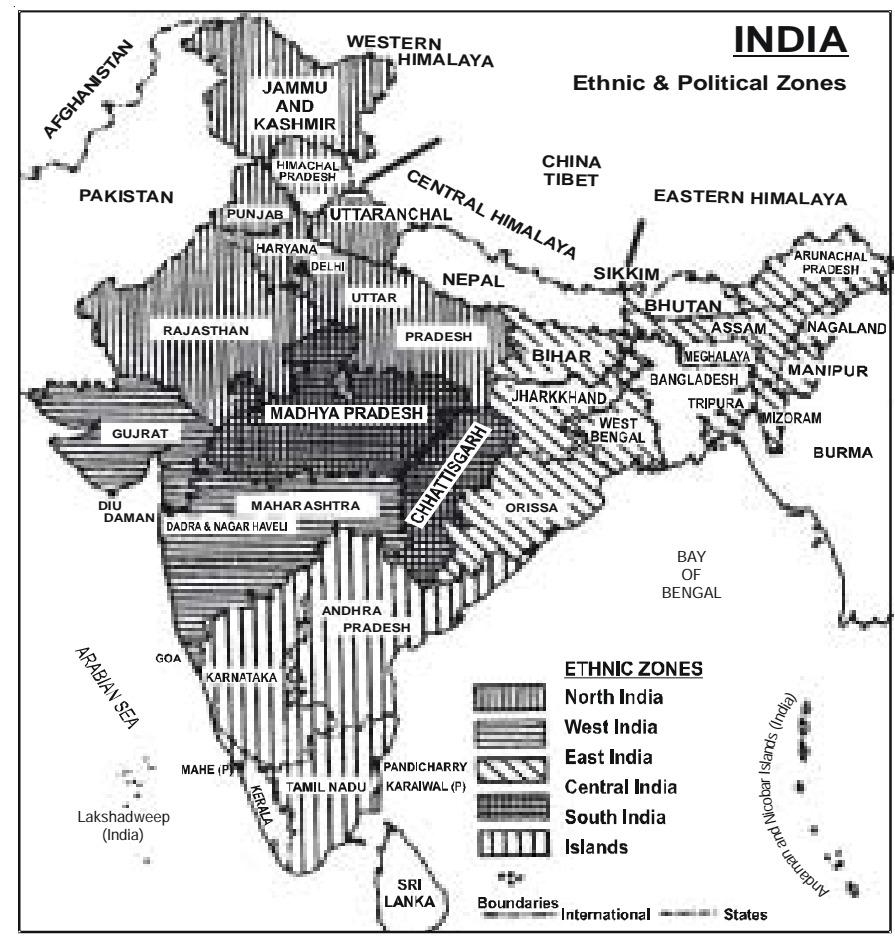

Fig. 8. India-Ethnic and Political Zones (after Bhasin 1988)

caste while the smaller group will be called a subcaste. These divisions and subdivisions are introduced on different principles. At theoretical level, Gotra or Got is derived either from the Gotrakara rishis of early Vedic time or from Gotra of some Brahman priests who ministered to a non-Brahman caste. In reality, Gotras are exogamous units of various kinds, territorial, occupational, totemistic and so forth.

At organization level considerable variation is found, caste mobility in few castes and in certain areas is a common factor. Theoretically, the caste definition seems to serve the purpose but the word caste, for example, "translates two vernacular terms with different meanings". In Northern India, the word 'Jat' (breed) and 'Qaum' (tribe) are synonymously used. The other word used is 'Biradari' or 'Bhaiband' (brotherhood). The 'Jat' is the caste as a whole, while 'Biradari' is the group of caste, who lives in a particular neighbourhood and act collectively for caste purposes. Quantitatively the 'Biradari' can be conceived as a fraction of caste, but qualitatively it can be conceived as a 'Jat' in action.
Ethnographic and genetic evidence both support that Hindu Castes have been highly endogamous for a considerable length of time (Karve 1968; Bhasin et al. 1994; Bamshed et al. 2001; Bhasin and Walter 2001; Misra 2001; Wooding et al. 2003). Although level of genetic differentiation between castes is relatively small, genetic distances observed suggest that gene flow is limited (Bhasin et al. 1994; Bamshed et al. 1998; 2001; Bhattacharya et al. 1999; Bhasin and Walter 2001; Dutta et al. 2002; Lakshmi et al. 2002)

It has been reported that paternally inherited DNA was overall more similar to Europenas than to Asians but, unlike in the case of maternal inheritance with no significant variation in affinity across the castes and this may be due to the migrating Eurasians populations are likely to be mostly males who integrated into the upper castes and took native women. Inter-caste marriages practices, while generally taboo, are occasionally allowed, in which women can marry into an upper caste and move up in the social hierarchy, whereas, such upward mobility, is not permissible for men because caste labels of men 
are permanent, but women, by means of their limited mobility, cause a gene flow across caste barriers (Bamshed et al. 2001; Basu et al. 2003; Kivisild et al. 2003).

\subsubsection{The Features of the Castes}

The feature of the castes are: hierarchy; endogamy and hypergamy (male of higher caste marrying a female of lower caste) occupational association; consciousness of caste membership and restriction on food, drink and smoking; distinction in dress and speech and confirmation to peculiar customs of particular caste; ritual and other previleges and disabilities; caste organization and caste mobility.

The essence of the caste is the arrangement of socio-economic hereditary groups than hierarchy. The popular impression of the hierarchy is derived from the idea of Varna with Brahman at the top and scheduled caste at the bottom. Only the two opposite ends of the hierarchy are relatively fixed, in between and especially in the middle regions, there is considerable room for debate regarding mutual positions. In a dispute over rank each caste would cite as evidence of its superiority the items of its diet, the other caste groups from which it accepted or refused to accept food and water, the ritual it performed and the custom it observed, its traditional privileges and disabilities and the myth of its origin. This fact of mutual position and arguments regarding it permit social mobility in certain areas. Mobility is not a recent phenomenon, but is restricted. All Hindus regard scheduled castes as being at the bottom of the ladder, but the category of scheduled castes is not homogeneous. In each linguistic area there are a few scheduled castes which form a hierarchy.

It cannot be said for certain when and in what circumstances the caste system originated. However, many theories have been put forward, which are as follows:

(1) Based on Colour: It is generally believed that in the early Vedic period there were no castes in Punjab. Only the fair skinned invaders called themselves Aryans and they called the dark skinned aborigines as Dasyus, Dasas or Asuras.

The term Varna (colour) is often confused with caste (Jati, Jat), though it is far from having the same meaning. The Rigvedic society was divided into four classes on the basis of Varna, three categories of twice-born (Dvija) —Brahman, Kshatriya and Vaishya, and fourthly the Sudra below whom were the outcastes.

(2) Based on Purushukta: In the Purushukta of the Rig-Veda, there is a mantra interpreted by scholars as such: "The Brahmans were born from the mouth of God, the Kshatriyas from his arms, and the Vaishyas from the thighs and Sudras from his feet." Some people regard this Mantra as the basis of the caste system.

(3) Based on Division of Occupation: After the Aryan invasion into Ganges valley, the stratification in the Indian society began. Social mechanisms were built up in order to carry on the organization of production and supply of services. One such well known mechanism was caste. Caste was not wholly an economic structure. Yet undeniably, it was built up on the basis of monopolistic guilds which were endogamous, each of these guilds grew up into separate caste. Exchange of goods and services was a highly stratified affair and each caste specialized in certain type of industry or delivery of goods. So each unit in the economic structure was virtually a monopoly of one caste and every tribe if possible was brought into more than one caste according to their specialization. Each caste or tribe was allowed to preserve its diverse sociocultural pattern as long as it did not give rise to conflicts with Brahmanical priesthood. Brahmans were trying for the uniformity of the rites and practices at a community level, local communities were allowed to carry on their modified version at family level.

Traditionally, each caste was associated with hereditary occupation and had a limited monopoly over it e.g. Brahmans (priestly and learning); Kshatriyas (warrior and aristocracy); Vaishyas (land owners and traders); and Sudras (crafts and service). It is not true to say that every member of the caste practised the associated occupation exclusively. It can only be said true of castes like Dhobi (washerman) and Kumhar (potter). However, generally speaking most practised agriculture along with their traditional occupation. Even agriculture as a single occupation cannot be associated with castes, as agriculture also means number of things: land ownership, tenancy and labour. Often the artisans and servicing castes do not earn enough from traditional occupation, so they augment their income by working as casual labourers or tenants on land. 
An analysis of the occupational statistics for 84 selected castes in 1931 showed that only 45 per cent of their members were following the traditional occupation (Census of India, 1931, Vol. 1, Part 2, pp. 416-19).

Occupations practiced by high and low castes are considered high and low, respectively. Manual labour is looked down and certain occupations like swine-herding and butchery are considered to be polluting and low.

Castes are governed by their own organization of authority. A greater uniformity has been retained at the economic level of caste than perhaps in relation to customs regulating marriage in particular. Though, there is a wide prevalence of the above model in all parts of non-tribal India, the system of economic inequalities has been encapsulated so to say, in regional moulds. The Saryuparis of Avadh (Uttar Pradesh), Namboodaris of Kerala, Chitpavans of Maharashtra, Chattopadhayas of Bengal and Iyengars of Tamil Nadu are all Brahman, but these categories are essentially regional. In the same way, the Jats of Haryana, the Bhumiyars of Bihar, the Reddys of Andhra and Vakilagas of Karnataka are cultivating castes, but the regional structure imposes boundaries which are generally recognised especially for inter-marriages. The Chamars of Uttar Pradesh, the Balais of Bengal, the Magirs of Gujarat, the Mahars of Maharashtra, the Malls of Andhra or the Adi-Dravidas of Tamil Nadu are all toiling scheduled castes but they are all highly concentrated in specific regions. It is, therefore, clear that, in spite of its wide prevalence, the caste system is, in many ways, also a regional phenomenon. The status and position of every caste group may be determined on an All India scale of social hierarchy, but the caste group itself, in many important respects is also a regional category.

\subsection{Scheduled Castes and Scheduled Tribes}

In the Indian censuses prior to 1931 , information was collected and published for each caste or tribe separately. In the 1931 census, data for individual communities was limited to (i) Exterior Castes (ii) Primitive Castes and (iii) all other castes with the exception of (a) those whose members fall short of four thousand of the total population and (b) those for which separate figures were deemed to be unnecessary by the local government.
In the 1941 census, 'group totals' were tabulated for scheduled castes, tribes and AngloIndians. For selected individual tribes separate tables were furnished. By 1951 census, community distinctions based on caste were being discouraged. It was decided to enumerate population on the basis of race, caste or tribe only to the extent necessary for providing information relating to certain special groups of the people who are referred to in the Constitution of India. The Scheduled Castes and Scheduled Tribes were enumerated from 1951 census onwards. The President by a special order scheduled particular castes among Hindus and Sikhs in particular areas for special treatment that also applies to tribes irrespective of their religious persuasion. The Scheduled Castes and Scheduled Tribes have been specified by 15 Presidential Orders issued under the provisions of Articles 341 and 342 of the Constitution. They are listed in Scheduled Castes and Scheduled Tribes Orders (Amendment) Act 1976.

The constitution prescribes protection and safeguards for the Scheduled Castes and Scheduled Tribes, and other weaker sections either specially or by way of insisting on their general rights as citizens with the object of promoting their educational and economic interests and of removing the social disabilities. However, in spite of all Governmental efforts, even when following the same profession as their neighbours, the Scheduled Castes and Tribes often have an inferior social status and are ruthlessly exploited by their employers and by money lenders.

In the Census of India 1991, 16.5 per cent of the population was enumerated as belonging to 'Scheduled Castes' or another 8.1 per cent as belonging to 'Scheduled Tribes' (Table 1). Thus roughly one in every four persons in India belongs to Scheduled Castes or Scheduled Tribes. There are, however, vast differences in the concentration pattern of Scheduled Castes in the different regions of the country. The fact

Table 1: Percentages of Scheduled Castes and Scheduled Tribes to total population 1961-91

\begin{tabular}{lcc}
\hline Year & Scheduled Castes & Schedueld Tribes \\
\hline 1961 & 14.67 & 6.36 \\
1971 & 14.60 & 6.94 \\
1981 & 15.75 & 7.76 \\
1991 & 16.48 & 8.08 \\
\hline
\end{tabular}




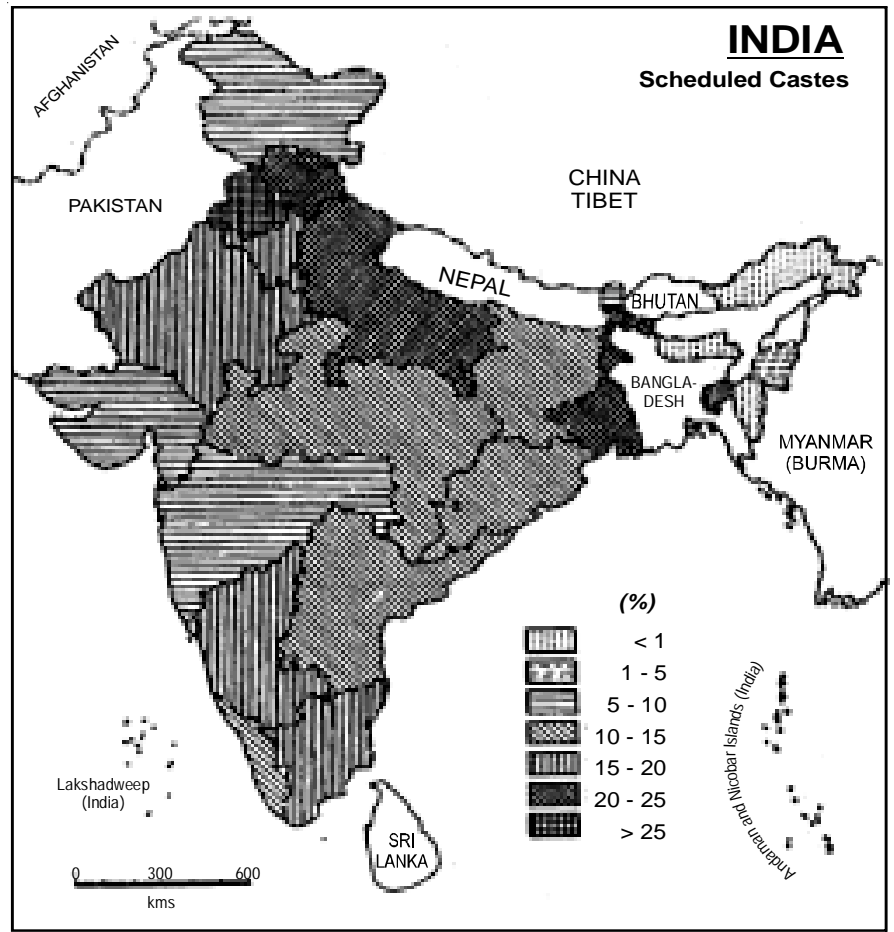

Fig. 9. India-Scheduled Castes in percent to the Total Population (after Bhasin and Walter, 2001)

that these castes are associated with agriculture explains their main concentration in the alluvial and the coastal plains of the country (Fig. 9). The hilly and the forested tracts of the tribal belt of the central and north-eastern India have only a sparse population of the Scheduled Castes.

The total population of the Scheduled Tribes in the states of Madhya Pradesh, Orissa, Bihar, Gujarat, Rajasthan, Maharashtra and West Bengal together accounts for about 80 per cent of the entire tribal population of the country (Fig. $3)$. On the contrary, the States and Union Territories with high tribal percentages have a far lesser share in the country's total tribal population. The tribal population of Mizoram, Lakshadweep, Arunachal Pradesh, Nagaland and Meghalaya accounts only one twentieth part of the total population of India.

Kivisild et al. (2003) reported that tirbes and castes share considerable Pleistocene heritage, with limited recent gene flow between them, whereas Cordaux et al. (2004) observed that caste and tribes have independent origins.

Ninety per cent of the Scheduled Castes are rural based and provide substantial support to Indian agriculture which is significantly more than that provided by Scheduled Tribes. The occupational structure of the Scheduled Caste work force is, by and large, made up of the following components:

(1) Landless agricultural labourers,

(2) Cultivators with small holdings,

(3) Small commodity producers or artisans,

(4) Services particularly of 'polluting' kind, and

(5) Industrial workers, mainly in industries related with their traditional crafts-leather tanning, shoe making etc.

Among the ethnic groups of India, the Scheduled Tribes hold a significant position. They belong to different ethnic, linguistic and religious groups having different economic organisation and socio-cultural characteristics.

In the census of 1951 the Scheduled Tribes were 5.35 per cent of the population of India.

In addition, some state governments have also specified other categories of people known as 'Other Backward Classes' and Denotified Nomadic and Semi-Nomadic communities. 


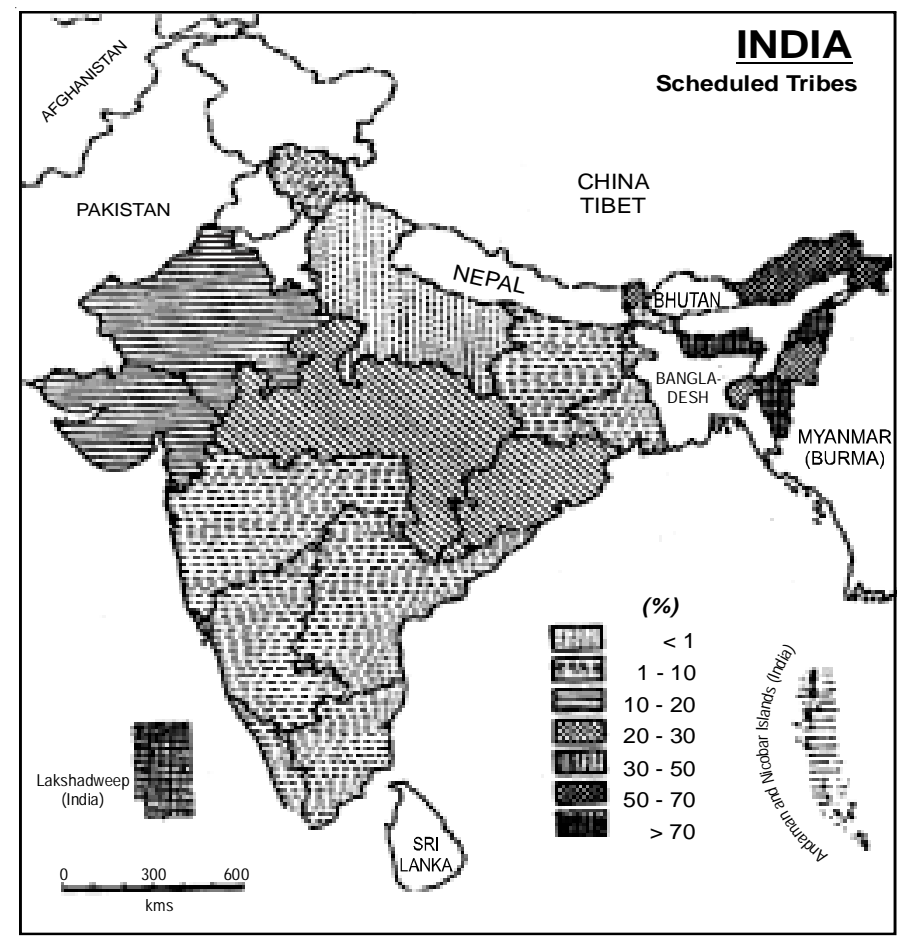

Fig. 10. India-Scheduled Tribes in percent to the Total Population (after Bhasin and Walter 2001)

According to Mandal Commission Report (1980) fifty two percent of the total population was belonging to Other Backward Classes (OBCs). The total number of identified OBCs that exist in the Central List is 3743 . The states with high percentages of total population of $\mathrm{OBCs}$ are Uttar Prdesh (38 percent), Rajasthan (28 percent), Gujarat (34 percent), Maharashtra (60 percent), Madhya Pradesh (50 percent), Karnataka (67 percent), Andhra Pradesh ( (44 percent) and Tamil Nadu (67 percent).

The caste system may have given stability to society but it is considered as an instrument that is responsible for the social disharmony, rivalry among different castes and exploitation with in and outside the castes. Social formation has emerged as a challenge to the hierarchical caste system based on Brahminical ideology

\subsection{Communities}

The population groups which have not been identifiable on the basis of caste system or are not denoted as tribes, have been referred by some authors on regional basis like Punjabis, Bengalese etc., by others on religion basis like Hindus, Muslims, Sikhs etc., by others on language basis like Telugus, Tamils etc. These authors have not specified or defined explicitly their caste and/or specific groups. All these groups have been classified under the category of community.

Confusion may be created if we assume that the surname attached to a name is the 'caste' name. Quite often these may be misspell or substituted with occupation, locality or religion. Quite often, as in the case of low castes who originally did not have the custom of writing a surname or caste or 'Gotras' name, use a high caste surname to identify themselves. Identification by name is thus fallacious. A caste group is best identified by tracing its social relationship, especially that of marriage. Endogamy most often defines the operational limits of a caste group. However, wider identification is possible with a region, language or occupation. Even then it is found that an endogamous group, even where it is cross-cutting geographical boundaries is likely to be identifiable as a social group in terms of 
caste ranking, social interaction, language, culture and sometimes even as a political grouping.

\subsection{Traditional Occupational Groups}

In the traditional society, there were occupational guilds. The chatur-varna system with its division into Brahman (priestly caste), Kshatriya (warrior caste), Vaishya (land owners and traders) and Sudra (labouring caste) was in fact based on occupational differentiation. The occupations are graded - manual labour is looked down upon and those dealing with swineherding, scavenging (removal of night soil) butchery are regarded as polluting. In table 2 is given a list of castes based on occupational division.

\subsection{Marriage Patterns}

People generally marry within a close-knit social circle in which many points of likes and dislikes are shared. The size of mating groups may be small or large, but if the preference operates over a long period of time, certain characteristics segregate and one population is marked off from another by visible differences.

Marriage patterns may be considered from the three aspects: the field of selection, the party to selection, and the criteria of selection. The restrictions posed among some tribes and communities in the field of selection are preferential and obligatory marriage. There are certain rules prohibiting marriage with certain relatives or between groups. The endogamous character of certain groups limits the boundaries or marital circles. Exogamous restrictions are defined in terms of sib, totem, territorial group, Gotra or Sapinda relationship (for detail see Kapadia 1982).

The Hindus have both endogamous and exogamous rules limiting the selection of mate. The Hindu society is divided into a number of endogamous caste groups each of which is further divided into endogamous groups based in terms of locality. This multiplicity of groups thus restricts the choice of mate within a boundary. Caste exercises a great influence on the social life of a man. The breach of caste endogamy was a punishable offence till recently. People were excommunicated by caste panchayat. With the advent of industrialization changes have taken place in the Indian society. One is the freedom in the matter of choice of occupation and secondly with the widening of area of social intercourse, intercaste marriages are taking place. The general attitude of the members of the caste concerned in such a union is either of non-opposition, tolerance or indifference.

The internal exogamous division of endogamous caste is Gotra or Sapinda. The rules of exogamy prohibit marriage between members of same Gotra; marriage between persons related to each other within certain generations on the father's and the mother's side. According to some scriptures the restrictions of Sapinda exogamy primarily implied marriage beyond the family i.e. four generations on the father's side and three on the mother's. The term Sapinda has two

Table 2: Caste based on division of occupation

\begin{tabular}{|c|c|c|c|}
\hline \multirow{2}{*}{$\begin{array}{l}\text { Social } \\
\text { status }\end{array}$} & \multirow{2}{*}{$\begin{array}{l}\text { Social } \\
\text { group }\end{array}$} & \multicolumn{2}{|c|}{ Economic activities } \\
\hline & & $\begin{array}{l}\text { Traditional } \\
\text { occupation }\end{array}$ & $\begin{array}{c}\text { Primary } \\
\text { occupation }\end{array}$ \\
\hline \multirow[t]{3}{*}{ I. High Castes } & Brahamans & Priesthood & $\begin{array}{l}\text { Priesthod, Agriculture, Trade and Commerce, } \\
\text { Armed Forces }\end{array}$ \\
\hline & Kshatriyas or Rajputs & Warfare & $\begin{array}{l}\text { Agriculture, Trade and Commerce } \\
\text { Armed Forces }\end{array}$ \\
\hline & Vaishyas (Banias) & Commerce & Trade and Commerce, Agriculture \\
\hline \multirow[t]{4}{*}{$\begin{array}{l}\text { II. Backward } \\
\text { (Middle) }\end{array}$} & $\begin{array}{l}\text { (a) Jats, Reddies, } \\
\text { Kammas, Vokalligas etc. }\end{array}$ & Agriculture & $\begin{array}{l}\text { Agriculture, Trade and Commerce, } \\
\text { Armed Forces }\end{array}$ \\
\hline & (b) Ahir, Gollas, & Animal & Animal Husbandry, Agriculture, Trade and \\
\hline & Gujars & Husbandry & Commerce \\
\hline & $\begin{array}{l}\text { (c) Porter, Barber, } \\
\text { Teli, Lohar etc. }\end{array}$ & Artisan & Artisan, Agriculture, Agricultural Labourers \\
\hline III. Low Castes & $\begin{array}{l}\text { Chamar, Dom, Bhangi, } \\
\text { Khatik }\end{array}$ & Menial Workers & Menial Workers, Agricultural Labourers \\
\hline
\end{tabular}


meanings: (1) those who share the particles of the same body; and (2) those who are united by offering balls of cooked rice (Pinda) to the same dead ancestors.

The Hindu Marriage Act of 1955 has upheld the Bombay legislation by removing the endogamous restrictions of caste and the exogamous restriction of Gotra from the condition of a valid marriage. The Act lays down the condition of a valid marriage, that the parties are not Sapindas of each other unless the custom or usage governing each other permits of a sacramental marriage between the two. The violation of this rule renders marriage void. According to the Act, marriage between two persons related within five generations on the father's side and three on the mother's is void unless permitted by local customs. Cross-cousin marriage in Southern parts of India is not only a valid marriage but preferential form of mating in that part of the country. In fact, cross-cousin marriage seems to have been a characteristic feature of the Dravidian peoples. In the kinship terminology of all three principal languages of this family, there is a clear indication of cross-cousin marriage. Among the Telugus, the Kannadigas and the Tamilians marriage with sister's daughter was also prevalent. The Hindu Marriage Act of 1955 has allowed cross-cousin marriage to continue as local custom but has prohibited marriage between uncle and niece. In some parts of South India the institution of domestic deity (mane deraru, vittu perumal) serves to define the exogamous unit in the absence of known genealogical links. In North India, high caste Hindus regard the village as an exogamous unit. Girls born within the village are called 'village daughters'.

In addition to endogamous marriage types, there are hypergamous and hypogamous marriages. Hypergamous marriage, in which the status of the bridegroom is socially higher than that of the bride, is known as anuloma i.e. with the grain; Hypogamous marriage, on the other hand is pratiloma, against the grain, that is, against what is natural or proper, since the status of the bride is in this case higher than that of the bridegroom. The significance of marriage pattern lies in the fact that the social hierarchy provides the basis, and the anuloma theory divine sanction for future hypergamy in India. Hypergamy occurs in different parts of India and was accepted by Brahmanical culture. With the growth of endogamous character of caste and social hierarchy, it became a more widely distributed pattern of marriage. It is known to exist among some Brahman castes such as Kulin, Audich, Khedaval and Anavils and among nonBrahman groups such as Marathas, Rajputs, Leva Patidars of Gujarat and Nambudiri Brahman of Malabar. The Kulin Brahmans are the highest among the three Jatis (Kulia, Bansaj and Sretriya) of Brahmans. Hypergamous marriages between different castes of Brahmans of Bengal were taking place, Leva-Patidar hypergamy of Gujarat is more intricate than Kulin hypergamy. The Patidar of Charotar are divided into thepeople of twenty six, twelve and finally, six villages respectively. The women of first group may marry men in the first, second and third group, while the women in the second group may marry men in second and third group, and the women in the third group may marry men in only the third group.

During Vedic period the favoured marriage pattern was monogamy, but polygynous and polyandrous marriages were also taking place. Polygyny is that form of union in which a man has more than one wife at a time. Polyandry is a form of union in which a women has more than one husband at a time, or in which brothers share a wife or wives in common. This form of union was once practised by the people of the CisHimalayan tract in Northern India and among some tribes of the Pre-Dravidian or Dravidian groups in South India. Though polygyny was allowed by the Hindu ideal of marriage it was resorted to only when no male child was born to the first wife within the first few years of marriage.

Levirate alliances are also prevalent among the Ahirs of Haryana, amongst Jats and Gujjars and several other castes in Uttar Pradesh, the Kodague of Mysore and some Muslim castes. In levirate marriage a man is obliged to marry the widow of a brother, and the children born to the new couple are their own.

Sororate alliances i.e. the marriage of a widower with his wife's younger sister, occur in South India.

A widower is permitted to marry in all religious groups, but it is not true for a widow. Widow remarriage is permitted among Muslims, Christians and Parsis. Among other groups local customs determine the question.

Among Muslims, parallel cousin marriage is preferential and obligatory. We have already seen that Muslim castes are also endogamous in practice though not in theory. The aristocratic 
Muslim caste Syed are divided into endogamous groups. Sometime the endogamous group is so small that it includes the extended families of man's parents. Such a group is called a Kufw while the maximal endogamous group is called Biradari.

Generally, among Christians and Muslims, the nuclear family is a exogamous unit. Lineage exogamy also exists among the Muslim Gujjars of Jammu and Kashmir. Some Muslims sub-castes are also endogamous, but the rules are not as strict as among Hindus. Hypergamous marriages do take place among Muslim converts to Islams from Jats and Rajput castes. Artisan castes which consider themselves mutually equal, intermarry among themselves.

The Sikhs are generally endogamous, though hypergamy does occur among them who are converts from Hindu castes $e . g$. Jats.

\subsection{Inbreeding}

In India each of the endogamous castes, tribes and religious communities has distinct and well-defined cultural norms, which include varied marriage customs/practices. Generally speaking, most of the Indian communities follow endogamy, but marriage within relatives is not permissible uptill the seventh generation. However, a few groups prefer marriages between related individuals like cross-cousins, parallel cousins, uncleniece etc. The type of preferential marriages vary across the country and different communities. For example whereas cross-cousin and parallel cousin marriages are preferred among the Muslims of the Northern India, the caste Hindus of Southern India prefer uncle-niece marriages.

Marriage between two individuals who have at least one traceable common ancestor is said to be consanguineous and the offsprings of such matings are inbred. There have been a number of studies in the recent past focussing attention on various aspects of inbreeding. But, it was Sanghvi (et al.) who initiated and stressed this kind of studies long back in 1956. After that, Dronamraju and Meera Khan (1961, 1963), Dronamraju (1963a) and others published extensive data from Andhra Pradesh. In 1966, Sanghvi again brought to light rather high rates of inbreeding in Andhra Pradesh and Maharashtra. Since then a large number of studies have been undertaken. With the help of consanguinity, Malhotra (1976) has put forward a generalization from which the following main features emerge:

(i) amongst both castes and tribes of Dravidian speaking states, (Andhra Pradesh, Kerala, Karnataka and Tamil Nadu) consanguineous marriages are preferred and prescribed; and that the coefficient of inbreeding is fairly high;

(ii) the castes in Indo-Aryan speaking areas (most of the Northern states) prohibit consanguineous marriages, the exception being Maharashtra, which has Dravidian influence on its marriage customs, and parts of Gujarat;

(iii) the position of tribal groups in the IndoAryan and Tibeto-Burman (North-East) speaking states is not clear; and probably low rates of consanguineous marriages would be discerned;

(iv) The Muslims, Christians of southern states, Delhi, parts of northern states like Jammu and Kashmir, Uttar Pradesh etc., West Bengal, Maharashtra and also Jews, Parsees etc. practice consanguineous marriages, however, their position is yet to be fully explored.

Roychoudhury (1976) noted in his comprehensive review that coefficient of inbreeding is highest in Andhra Pradesh. It varies from 0.013 to 0.041 depending on the social or religious communities that are studied within the state, it is highest among fishermen (0.047, Sanghvi 1966) and tribals (0.041, Veerraju 1973) followed by Hindus (varies from 0.022 to 0.033, Sanghvi 1966).

However, many other studies (among others-Dronamraju and Meera Khan 1963; Chakravartti 1968; Murty and Jamil 1972; Reid 1973; Veerraju 1973; Pingle 1975; Rao and Mukherjee 1975; Reddy 1983) show contradictory reports regarding the inbreeding coefficients of different tribes and castes in Andhra Pradesh. But, it is generally viewed that Hindus have quite high inbreeding coefficients followed by various tribes, Muslims, Christians, etc.

From Roychoudhury's (1976) review, it was also possible to have an account of frequent types of consanguineous marriages in India as well as in Andhra Pradesh and other southern states (having higher rates ofinbreeding). The most frequent type of consanguineous marriage is between first cousins. There are four kinds of first cousin marriages, namely, the marriages with mother's brother's daughter (MBD), father's 
sister's daughter (FSD), mother's sister's daughter (MSD) and father's brother's daughter (FBD). The first two are cross-cousin marriages and last two are parallel-cousin marriages. The Hindus practise cross-cousin marriages and prefer to marry MBD or FSD, while the Muslims practise both. Marriage with elder sister's daughter or uncle-niece marriage though prevalent among Hindus (but frequency is quite low), is forbidden among Christians or Muslims.

The reasons for high frequency and degree of inbreeding (especially in southern states of India) are believed to be influenced mainly by various socio-economic and cultural factors (Reddy 1983). However the geographical barriers between the communities or physically isolated groups are very few. This is clear from the fact that even the size of 'small' castes or tribes (in most of the cases) are large enough to permit the choice of unrelated spouse (Dronamraju and Meera Khan 1963). Only in some small restricted isolates, besides preference for consanguineous marriages, lack of choice accounts for high frequency of inbreedings.

Dronamraju (1963a), while discussing high rates of inbreeding in Andhra Pradesh, outlined the possible reasons. The most important ones seem to be (a) to keep the cultivable land in larger pieces for growing food crops, (b) the parental domination in arranging the marriage, (c) the mutual knowledge of families, (d) the relatives are better suited for economic and other reasons, to fit into the Hindu joint family system etc.

Bhasin and Nag (1994) have attempted to put forward a comprehensive review of incidence of consanguinity, viz., fertility, mortality, morbidity in the Indian region and other South Asian countries-Bangladesh, Bhutan, Maldives, Nepal, Pakistan and Sri Lanka.

They observed that in Indian region incidence of consanguineous marriages has not declined yet. Such types of marriages are preferred not only in small isolates or geographically restricted communities, but also in numerically large castes, communities and tribes (various caste Hindus, Muslims, Christians, Buddhists, Parsis, Jews and Scheduled Tribes) mainly due to diverse socioeconomic and cultural reasons. Regional appraisal shows that the states of the southern region of India overwhelmingly prefer and practice consanguineous marriages across all major religious groups and ethnic entities except Kerala, where comparatively low incidence is observed, owing perhaps to higher educational status, influence of Christianity and absence of a major type of consanguineous marriage (prevalent especially in the southern states), those between uncle-niece. In the western region, the marriage customs of many communities of Maharashtra, seem to submit to Dravidian influence thereby preferring consanguineous marriages fairly frequently. In the other states of western region; and the northern region, eastern region, Islands and other South Asian countries, except among Muslims and certain tribal groups, consanguinity is usually proscribed or preferred occasionally. They further added that consanguinity is often positively related with fertility, mortality, morbidity, and sterility. But there also exist contradictory evidences leading to ambiguities and therefore, such generalized notions may require future revision.

However, it is apparent today that higher education, industrialisation and urbanisation etc. are reducing the frequency of consanguineous marriages as they are negatively correlated.

\section{Religious Groups}

In the present book, studies have not been categorised into various religious groups for the statistical analysis, however to facilitate a comparative discussion, a brief text on the different religious groups is given below.

In India, several religions have flourished since time immemorial. India is the original home of Hinduism, which constitutes the system of beliefs and rituals of the majority of its people. The major religious groups are Hindus, Muslims, Christians, Sikhs, Buddhists and Jains and each account for not less than a million populations in the country as a whole. A total of 183 other religions under the head 'Other Religions and Persuasions' have been recorded in Census of India 1981 with the strength of 100 and above, at the country level.

\section{1. Hindus (Hinduism)}

Hinduism has developed gradually out of the synthesis of sacrificial cults brought into India by the Aryan invaders around 1500 B.C. with religion of various indigenous people. In historic times the complexity of religious belief, custom, and practice has been influenced by Zoroastrianism, Christianity, Islam, the tribal religions of Central 
Asian Nomads and perhaps even Chinese Taoism. The most characteristic feature of Hinduism, however, is the doctrine of an eternal soul and its rebirth. Even in its classical period (600 B.C. to 450 B.C.) Hinduism was characterized by an astonishing variety of doctrines and cultures. It was regarded, however, as a retrograde step when these varieties of culture, ritual and mythology became hardened into social strata and castes. The distribution of Hinduism is widespread, throughout the length and the breadth of the country.

Almost the entire country with the exception of the extreme North in North Western corner and the North Eastern corner shows that Hindus form over 80 per cent of the total population. There is a distinct continuous stretch of the country constituting the entire Orissa state, adjoining areas of Andhra Pradesh and a large adjoining tract of Madhya Pradesh, where the population is almost entirely (about 90 per cent or more) made up of Hindus. There is another distinct area of Himalayan region (Himachal Pradesh and Uttar Pradesh), which is also mostly Hindu in its population composition.

\section{2. Muslims (Islam)}

Islam began in Arabia in the beginning of the 7 th century. The founder of this religion was Prophet Muhammad who was born in 570 A.D. in a distinguished family of Mecca. After Prophet Muhammad's death (A.D. 632) the leadership passed to Calipus or Khalifas who were both religious and political heads. Arabs spread Islam from the Atlantic to Sind within eighty years of Prophet's death.

Though Islam proclaimed the idea of equality, but in India it has been characterized by caste. The true Muslims are divided into four large families-Saiyad, Shaikh, Pathan and Moghul. Though they are referred as castes in India, they are neither castes nor tribes but are merely names given to groups of tribes supposed to be of similar blood (Blunt 1931: p. 189).

Muslims are divided into two major religious, endogamous sect-Shia and Sunni and several minor groups like Momins, Domon, Khoja, Bohra, Moplahic.

In addition there are interior and exterior castes among Muslims- (a) Ashraf or Sharif meaning noble or person of high extraction. It includes all undoubted descendants of foreigners and converts from higher Hindu castes. (b) Ajlaf Alrop - meaning "wretches", embraces all other Mohammedans, including the functional groups and low ranking converts.

Traditional occupation of Saids is the priesthood, while the Moghuls and Pathans correspond to Kshatriyas of the Hindu regime. All converts are endogamous groups and many are split into further smaller endogamous groups "amongst the Bhands, Gujjars and Rangrej, Sunis and Shias do not intermarry...; Pathan and Shaikh. Muhammadan Rajputs preserve their Hindu rules of hypergamy". "In fact, most of these castes of Hindu converts preserve some trace of their former marriage system", (Blunt 1931:pp. 201-202). Certain Muslim groups also preserve Hindu commensal taboos and religious rites. The Muslims are a predominantly rural community with marked concentration in the Kashmir valley and adjacent Kargil Tehsil, Mewat, Rohilkhand and upper Doab, Ganga Delta, Malasar and the Lakshadweep.

The States and Union Territories, where Muslims are predominant, are Lakshadweep (94.84 per cent) and Jammu and Kashmir (64.19 per cent). The States in which the proportion of Muslims exceeds the national average (11.35 per cent) are West Bengal (21.51 per cent), Kerala (21.25 per cent), Uttar Pradesh (15.93 per cent) and Bihar (14.13 per cent).

\section{3. Christians (Christianity)}

It is believed that Christianity was introduced in South India in the first century A.D. by St. Thomas, who, according to the Catholic Church of Edessa, came twice on missions to India. Cosmas of Alexandria, who travelled in South India (A.D. 522), found two Mestorian Churches - one in Quilon and other in Ceylon. A copper plate grant of A.D. 744 attests to the fact that many Indians have become converts to Christianity. The immigrants from Baghdad, Nineveh, Jerusalem and other places added to the Christian community. Marco Polo (A.D. 1293) mentions the presence of a Christian community at St. Thomas Mount and narrates a story of the martyrdom of St. Thomas on the mount.

Indian Christians are divided into Catholics as well as Protestants. The caste restrictions are rigidly observed among Christian community, a high caste Catholic will marry a Catholic of high caste and similarly Protestants will marry among themselves. It can be concluded that the whole 
Indian society is caste ridden and caste system, in one or the other form, is present in all religions.

Christians constitute the third major religious community in the country. Christianity appears most widespread in the Southern and Northeastern regions of the country. In Kerala, Tamil Nadu, Andhra Pradesh about 60 per cent of the entire country's Christian population is accounted for. In North Eastern states like Nagaland, Meghalaya and Mizoram, the composition of the population is predominantly Christian.

\section{4. Sikhs (Sikhism)}

The word Sikh is the Punjabi form of the Sanskrit word 'Shishya' which means disciple. The Sikhs are the followers of Guru Nanak Dev and nine other Gurus of whom the last was Shri Guru Govind Singh. Sikhism was based on the teachings of Unity of God; rejection of caste and ritualism and brotherhood of man. Though based on the idiom of equality, Sikhism is as caste ridden as Hinduism. Sikhs are broadly divided into Sardars and Majhabis, the former consisting of high castes and latter of sweepers. The Sardars include Jat and Kamboh (Landowners), Tarkhan (Carpenter), Kumhar (Potter), Mehra (Water carrier) and Cimbma (Washer man). The first two castes regard themselves as superior to the others. Majhabis are later converts. In some parts of Punjab, Sansi (Shepherd), the members of criminal tribe are later converts and are at lowest level. There are some other religious sects among the Sikhs like Nihangs, Namdharis and Ramgarhias. The Sikhs though extremely mobile are concentrated in all districts of Punjab and parts of Haryana.

In Punjab 60.75 per cent and in Chandigarh 21.11 per cent of the population is Sikhs. In no other state or Union Territory do they constitute even 5 per cent of the population except in Haryana (6.21 per cent) and Delhi (6.33 per cent).

\section{5. Buddhists (Buddhism)}

Buddhism was evolved as a revolt against Vedic religion or Brahmanism. In the sixth century B.C., number of new sects sprang up, and Buddhism was one of them. Buddhism was founded by Kshatriya Prince Siddartha and was based on the principles of non-violence and simple living instead of ritualism. Buddhism is further divided into two sects: (i) Hinayan (The Small Vehicle)-Old followers of the old religion who believed in Buddha as a Guru or the Great Master.

(ii) Mahayanas (The Great Vehicle)-They raised Buddha to the position of a saviour god.

Taking the country as a whole the largest number of Buddhists is found in Maharashtra. It is well known that the neo-Buddhist movement during the decade 1951-61 saw a large scale adoption of Buddhism particularly by the Scheduled Castes population in Maharashtra, though this tempo was not maintained in 196171 ; in fact the growth rate recorded appears to be less than even the natural growth rate. It is possible that certain converts from Scheduled Castes to Buddhism preferred to return their religion as "Hindu" finding that as Buddhists they were not entitled to certain concessions available to Scheduled Castes.

In North Eastern states the Buddhists account for 28.71 per cent in Sikkim, 13.69 in Arunachal Pradesh and 8.19 per cent in Mizoram.

\section{6. Jains (Jainism)}

The other sect which evolved against Brahmanism, was Jainism founded by another Kshatriya Prince Vardhaman. It also laid stress on right actions and good deeds instead of sacrifices and prayers. Jains are further divided into two sects-

(i) Svetambara - clothed in white

(ii) Digambara - clothed in atmosphere, because their Munis wear no clothes.

The Jains are essentially urban dwellers; this is the only religious community which is more numerous in urban areas than in rural areas. They are spread largely in States of Rajasthan, Maharashtra, Gujarat, Madhya Pradesh, Karnataka and Union Territory of Delhi.

\subsection{Parsis}

An endogamous group migrated from Iran and settled primarily in West India. They show a high frequency of inbreeding. They were Zoroastrian fire worshippers, and came to India [as their name suggests from Fars (Persia)] about 8th century A.D. to escape from forcible conversion to Islam. In 1981, they were only 71,630 in India (Census of India 1981).

\subsection{Jews}

Indian Jews are divided into: Beni-Israel, 
Cochin Jews and Baghdadi Jews. Beni-Jews, who are mostly found in Bombay, are again divided into Gora (White) and Kala (Black), the former being considered higher in rank. The Cochin Jews, found mostly in Cochin, are divided into three categories-Gora, Kala and Meshurarim (descendants of Cochin Jews and their slave concubines). The Baghdadi Jews are found in Bombay and Calcutta. They were 5618 in India (Census of India 1981).

\section{Linguistic Groups}

The people of India display a high degree of diversity in their languages and dialects. It has been acquired through a long process of peopling of the sub-continent by heterogeneous ethnic groups drawn from the neighbouring regions of Asia. A linguistic group is an entity of social significance. There is a broad social integration among all the speakers of a certain language. In the beginning languages and dialects developed in the different regions of the country under conditions of more or less isolation. The language and the dialect thus play a significant role in defining the elements of regional identity.

In free India the distribution pattern of major language groups was considered as a satisfactory basis for the formation of states. This has given a new political meaning to the geographical patterns of the linguistic distribution of the country.

According to Grierson (1903-1928), India has 179 languages and 544 dialects. Of these languages (the separate enumeration of dialects is irrelevant, since they also come under "languages"), 116 are small tribal speeches of the Tibeto-Chinese family; these are found only in the northern and north-eastern fringes of India and are present among less than 1per cent of the entire population of the country. Nearly two dozen more are likewise insignificant speeches of other language groups; or they are languages not truly belonging to India (Census Centenary Monograph No.10, 1972; Gazetteer of India 1973).

According to the 1961 Census of India there were 187 languages spoken by different sections of our society. This is, however, not surprising, considering a large number of people inhabiting a vast land. The picture though becomes less confusing when it is noted that as many as 94 of these 187 languages are spoken by less than 10,000 persons each and that 23 languages together account for 97 per cent of the total population of the country. Out of these 23 languages, 15 besides English have been specified in the Eighth Schedule of the Constitution of India. These are Assamese, Bengali, Gujarati, Hindi, Kannada, Kashmiri, Malayalam, Marathi, Oriya, Punjabi, Sanskrit, Sindhi, Tamil, Telugu and Urdu. Hindi has been given the status of India's official language along with English. Sanskrit included in the list is no longer a spoken language, though it has great importance even today. The Eighth Schedule does not recognize any of the languages belonging to the Austro-Asiatic and TibetoChinese families, because of their numerical as well as cultural insignificance.

\subsection{Classification of Indian Languages}

The languages spoken by the people of India (Fig. 11) belong to the following four language families:

4.1.1. The Austro-Asiatic Language Family (Nishada),

4.1.2. The Tibeto-Chinese Language Family (Kirata),

4.1.3. The Dravidian Language Family (Dravida), and

4.1.4. The Indo-European Language Family (Aryan).

"It is not known how and when these language families moved into India. Before their advent, there was the language of the Negroid peoples, who pioneered into India from Africa along the Asian coastline probably before the 6th millennium B.C. But on the mainland of India nothing has remained of their language, the original Negroid peoples having been killed or absorbed by subsequent immigrants" (Gazetteer of India 1965).

Chronological sequence in the matter of the advent into India of the three groups other than Aryan has not been established. It is not clear as to who came first - the Austro-Asiatic, TibetoChinese or Dravidians. But the fact remains that all these three groups were in India when the Aryans came.

Renfrew $(1987,1989)$ and Cavalli-Sforza et al. (1994) reported that Indian sub-continent had experienced massive gene flow from at least two Neolithic episodes of migrations. Firstly about 10-15 thousands years ago, when agriculture developed in the fertile cresent region, a part of an eastward wave of human migration entered 
India and brought Dravidian languages (Renfrew 1989) mainly, Elamo-Dravidian languages (Ruhlen 1991), which may have originated in the Elam province (Zagros Mountains, Southwestern Iran) and are confined to southeastern India and to some isolated groups in Pakistan and northern India. The next was the arrival of pastoral nomands from the central Asian steppes to the Iranian plateau about 4000 years before present, brought with it the Indo-European language family which eventually replaced Dravidian languages from most of Pakistan and northern India, perhaps by an elite-dominance process (Renfrew 1987, 1989, 1996, Cavalli-Sforza et al. 1988; Quintana-Murci et al. 2001)

Out of these language families, the Aryan family is numerically and culturally the most important in India. According to 1961 Census of India over 73.3 per cent of the Indian people spoke languages belonging to the Aryan family. Dravidian came next representing 24.47 per cent. There are only 1.5 per cent for the Austric languages and still less for the Tibeto-Chinese languages ( 0.73 per cent).

\subsubsection{The Austro-Asiatic Language Family (Nishada)}

"Between the Austrics and Dravidians, the former possibly represent the earlier group. According to some scholars, the Austrics had their origin in Indo-China and South China; they spread east into India and south into Malaya, and then passed into the islands beyond. Another view, which is more recent is that the Austrics are a very old off-shoot of the Mediterranean people who came into India from the west, probably even before the Dravidians. Austric speech influenced Dravidian and Aryan. In the plains, Austric has been very largely suppressed by Dravidian and Aryan, but Austric languages survive in the less easily accessible hills and forests of Central and Eastern India. On the Himalayan slopes, Austric languages have deeply modified the Tibeto-Chinese dialectsthese took over some Austric features. In Assam, one Austric language survived among the Khasis, who are largely Mongoloid in race but Austric in speech" (The Gazetteer of India 1965).

The Austro-Asiatic family is represented in India by the speakers belonging to the two main branches-(i) Mon-Khmer Branch (Mon-Khmer Group) and, (ii) Munda Branch (Munda Group). (i) Mon-Khmer Branch: This includes the two groups-1. Khasi group of languages of Assam, and 2. Nicobarese of the Nicobar Islands.

(ii) Munda Branch: This is represented by the speakers belonging to the Central and Eastern regions of India. This is the largest of the AustroAsiatic family. This includes the people inhabiting mostly the hills and jungles of Bihar, Chota Nagpur, Orissa and Central India. The largest single group is that of Santhali speakers, who alone account for more than half of the total Austro-Asiatic speakers. The names of the speeches in the branch are given below:

1. Kherwari 2. Santali 3. Mundari 4. Bhumij 5. Birhor 6. Koda/Kora 7. Ho 8. Turi 9. Asuri 10. Agaria 11. Birjia/- Brigia/Binjhia 12. Korwa 13. Korku 14. Kharia 15. Juang 16. Savara 17. Gadaba and Munda - unspecified.

Of the two speeches of Mon-Khmer, Khasi is confined to the Khasi and Jaintia Hills of Meghalaya, while Nicobari to the Nicobar Island in the Bay of Bengal. The Mundari speakers are concentrated in the tribal districts of Santal Parganas, Mayurbhanj, Ranchi, East Nimar, Betul and Baudh Khondmals.

\subsubsection{The Tibeto-Chinese Language Family (Kirata)}

"The original Sino-Tibetan speakers appear to have become characterized with their basic language at least 4000 years before Christ in the area to the west of China, between the sources of the Yangtze and the Hwang Rivers. There they developed a language which ultimately became the source of Chinese, Tibetan, Burmese and possibly also Thai, though the genetic connection of Thai with the Sino-Tibetan family is now being questioned. The Tibeto-Burman speaking Mongoloids with yellow complexion came to be known among the Vedic Aryans as the Kiratas. The Kirata influence in the amalgam of Aryo-Dravido-Austric culture, which is Indian culture or Hindu culture, was not very farreaching. The role of the Sino-Tibetan languages and their present position also are not very significant" (The Gazetteer of India 1965).

The speakers of Tibeto-Chinese family of languages are people of Mongoloid origin, who are considered to have entered the Indian frontiers much earlier than the Indo-Aryan speakers. The area of the speeches stretches right from Baltistan in the west to the north-eastern 


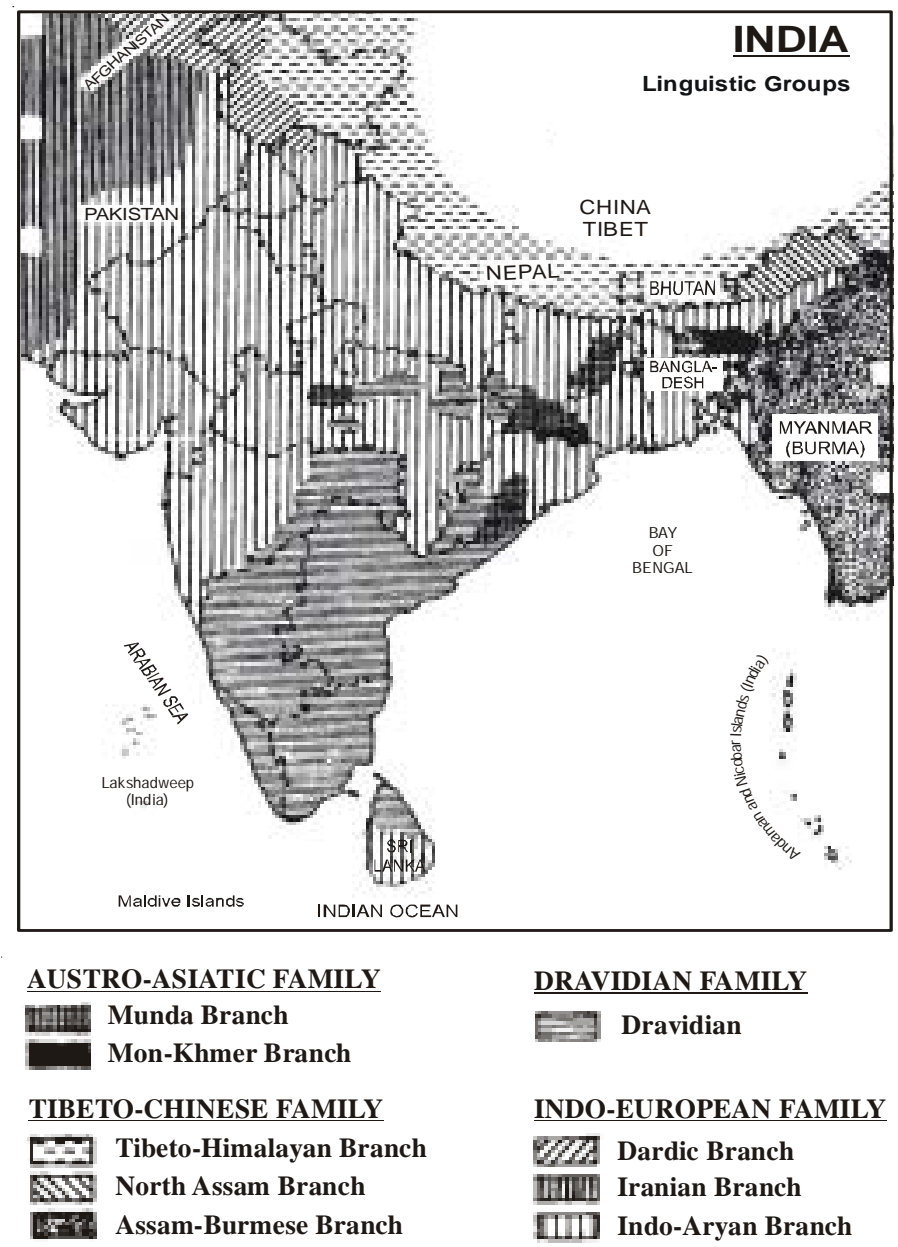

Fig. 11. India-Linguistic Groups (after Bhasin, Walter, Danker-Hopfe 1994)

frontiers of the country and further reaching up to the southern most portions of Assam.

The speakers of Tibeto-Chinese family fall into two main sub-families-I. Siamese-Chinese SubFamily and, II. Tibeto-Burman Sub-Family.

I. Siamese-Chinese Sub-Family: It includes the Tai Group of languages which is distinct from Tibeto-Burman, and is represented only by one language i.e. Khamti.

II. Tibeto-Burman Sub-Family: The second sub-family of Tibeto-Chinese Family is divided into three branches-(a) Tibeto-Himalayan Branch; (b) North-Assam Branch; and (c) AssamBurmese Branch.

(a) Tibeto-Himalayan Branch: This branch consists of the following groups: (i) Bhotia Group (Tibetan Group)

(ii) Himalayan Group

(i) Bhotia Group (Tibetan Group): This group is represented by a number of important numerically strong speeches within Indian borders, namely: Ladakhi, Lahuli, Sikkim Bhotia, Balti and a number of small communities combined under the common name of Bhotia. This group includes the following languages:

1. Tibetan 2. Balti 3. Ladakhi 4. Lahauli 5. Spiti 6. Jad 7. Sherpa 8. Sikkim Bhotia 9. Bhutani 10. Kagate and Bhotia-Unspecified.

(ii) Himalayan Group (Pronominalized/ Non-pronominalized Himalayan Groups): This group of speeches is spoken along the tracts to the south of the Himalayas from Himachal 
Pradesh in the west to the western borders of Bhutan in the east. These are further split into pronominalized and non-pronominalized groups of speeches. The pronominalized group of speeches has given evidence of Austro-Asiatic traits remaining in some of their member speeches. This group includes the following speeches:

1. Lahauli of Chamba 2. Kanashi 3. Kanauri 4. Jangali 5. Dhimal 6. Limbu 7. Khambu 8. Rai 9. Gurung 10. Tamang 11. Sunwar 12. Mangari 13. Newari 14. Lepcha 15. Kami 16. Toto.

(b) North-Assam Branch: A significant group of languages the Tibeto-Burman sub-family occupies the north-eastern frontier and may be named as 'North-East Frontier Group'.

North-East Frontier Group: This group consists of a number of following languages:

1. Aka/Hrusso 2. Dalfa 3. Abor/Adi 4. Miri 5. Mishmi

(c) Assam-Burmese Branch: This branch of Tibeto-Burman sub-family consists of the following groups:

(i) Bodo Group (Bara or Bodo Group); (ii) Naga Group; (iii) Kachin Group (iv) Kuki-Chin Group; (v) Burma Group

(i) Bodo Group (Bara or Bodo Group): This group includes the following languages:

1. Bodo/Boro 2. Lalung 3. Dimasa 4. Garo 5. Koch 6. Rabha 7. Tripuri 8. Deori 9. Mikir.

(ii) Naga Group: This group consists of the following languages:

1. Angami 2. Sema 3. Rengma 4. Khezha 5. Ao 6. Lotha 7. Tableng 8. Chang-Naga 9. Kacha Naga 10. Zemi Naga 11. Kabui 12. Khoirao 13. Mao 14. Maram 15. Tangkhul 16. Maring 17. Konyak 18. Pochury 19. Phom 20. Yimchungre 21. Khiemnungam 22. Nocte 23. Wancho 24. Makware 25. Tangsa and Naga-Unspecified.

(iii) Kachin Group: This group includes the two languages:

1. Kawri 2. Singpho.

(iv) Kuki-Chin Group: It consists of the following speeches:

1. Manipuri/Meithei 2. Thodo 3. Ralte 4. Paite 5. Tlangtlang 6. Pawi 7. Lakher 8. Lushai/Mizo 9. Rangkhol 10. Halam 11. Langrong 12. Aimol 13. Chiru 14. Kom 15. Hmar 16. Lamgang 17. Chote 18. Purum 19. Anal 20. Gangte 21. Vaiphei 22. Khami 23. Khawathlang 24. Simte and KukiUnspecified and Chin-Unspecified.

(v) Burma Group: This group includes the speeches: 1. Mru 2. Arkanese

The languages and the dialects belonging to the Sino-Tibetan family are spoken by tribal groups of north-east and of the Himalayan and sub-Himalayan regions of the North and NorthWest. The speeches of the Tibeto-Himalayan branch are spoken in Ladakh and parts of Himachal Pradesh and Sikkim. The AssamBurmese Branch is concentrated in the states of North-east India along the Indo-Burmese border. Among these, Naga dialects are spoken in Nagaland; Lushai is concentrated in Mizo Hills, Garo in Garo Hills and Meithei in Manipur.

\subsubsection{The Dravidian Language Family (Dravida)}

"The Dravidians are said to have come from Asia Minor and the Eastern Mediterranean. They were a Mediterranean people, of the same stock as the peoples of Asia Minor and Crete, and the Pre-Hellenic people of Greece (The Aegean). The Dravidians of India were thus originally a branch of the same people as the Pre-Hellenic people of Greece and Asia Minor. The exact affiliation of Dravidian with the language of the Eastern Mediterranean has not yet been settled. But some common lexical elements are noticeable. Certain religious notions and ideas as well as cults and practices among the Dravidian people of India have strong West Asian and Mediterranean affinities. The city civilization of Sind and Punjab and other parts of India appears to be Dravidian, and therefore connected with West Asia. The Dravidian languages are now found in solid blocks in the Deccan and in South India, where they have their separate existence in spite of strong inroads upon them by the Aryan speech. There is an Austric element in the Dravidian languages, just as there is a strong Dravidiancum-Austric substratum in the Aryan speeches of India (The Gazetteer of India 1965).

The language families have been broadly grouped geographically and the relative position of particular language is discussed with reference to its situation in three broad group areas. They are listed below:

(i) South Dravidian Group: It consists of the speeches: 1. Tamil 2. Malayalam 3. Kannada 4. Coorgi/Kodagu 5. Tulu 6. Toda 7. Kota 8. Telugu.

(ii) Central Dravidian Group: It includes 1. Kui 2. Kolami 3. Gondi 4. Parji 5. Koya 6. Khond/ Kondh 7. Konda.

(iii) North Dravidian Group: It includes 1. 
Kurukh/Oraon and 2. Malto.

Unspecified Dravidian Tongues: A few (6742) persons belong to unspecified Dravidian Tongues, which are 1. Dravidian, 2. Madrasi, 3. Ladhadi and 4. Bharia.

Languages of the Dravidian family are concentrated in the plateau region and the adjoining coastal plains. Telugu is spoken in Andhra, Tamil in Tamil Nadu, and Kannada in Karnataka and Malayalam in Kerala. The speeches of the Dravidian family are also spoken by a large number of tribal groups living in the eastern and the north-eastern parts of the peninsular plateau. These groups include the Gonds of Madhya Pradesh, Central India and the Oraons of Chota Nagpur Plateau.

\subsubsection{The Indo-European Language Family (Aryan)}

"The Aryan speeches of India, beginning from Vedic Sanskrit, their oldest form, have been the great intellectual and cultural heritage of India. They form our mental and spiritual link with the European world, on the genetic side; and with the world of South-East Asia and East Asia, on the cultural side, through Buddhism and Brahmanism. The modern Indo-Aryan languages of India are near or distant cousins of the IndoEuropean languages outside India, like Persian, Armenian, Russian and other Slav languages; Greek, Italian, French, Spanish and other Latin languages; German, English, Norwegian and other Teutonic languages; and Welsh and Irish among Celtic languages. The Indo-European speechfamily is today the most important in the world. With the exception of the various languages within the orbit of Chinese (the so-called dialects of Chinese or Han), Japanese, Indonesian or Malay, and Arabic, all the main languages of the world, and the most important culturally, are IndoEuropean. And all these languages are descended from a common source-speech, the "Primitive Indo-European", which flourished about 5000 years ago" (The Gazetteer of India 1965).

In India this great family is represented by its sub-family of languages, which covers the widest area of the country and is spoken by the largest proportion of the Indian population.

I. Aryan Sub-Family

The Aryan sub-family is further divided into 3 branches-(a) Iranian Branch (b) Dardic (or Pisacha) Branch, and (c) Indo-Aryan Branch. (a) Iranian Branch: It is represented by languages like Persian, Pashto and Balochi considered of foreign origin.

(b) Dardic (or Pisasha) Branch: It is represented by following groups of languages:

(i) Kafir Group : Wai Ala

(ii) Khowar Group: Khowar

(iii) Dard Group: 1. Dardi 2. Shina 3. Kashmiri 4. Kohistani. Speakers of Kafir and Khowar groups do not come within the Indian boundaries.

(c) Indo-Aryan Branch: The coverage of the language of the Indo-Aryan Branch being much too wide, it will perhaps be convenient to restrict the brief description of the main languages and dialects of the branch through enumeration of broad groups of languages classified in their proper circles with reference to common characteristics and socio-linguistic tendencies, often not found in the other groups. The IndoAryan Branch can be divided into two subbranches as follows: 1. Outer Sub-Branch and 2. Mediate Sub-Branch/Inner Sub-Branch

1. Outer Sub-Branch: This consists of the following

(i) North-Western Group: This includes 1. Lahnda or Western Punjabi Dialects and 2. Sindhi.

(ii) Southern Group: This group includes 1. Marathi; 2. Konkani.

(iii) Eastern Group: This includes 1. Oriya; 2. Bihari with sub-groups- Bhojpuri, Maghi/ Magadhi, Maithili; 3. Bengali; 4. Assamese.

2. Mediate Sub-Branch/Inner Sub-Branch: This includes the groups-(i) Mediate Group/ Central Group and, (ii) Pahari Group.

(i) Mediate Group/Central Group: This includes-1. Hindi; 2. Hindustani; 3. Urdu; 4. Punjabi; 5. Gujarati; 6. Bhili; 7. Khandeshi; 8. Rajasthani.

(ii) Pahari Group: It is divided into-1. Eastern Pahari; 2. Central Pahari; and 3. Western Pahari

Grierson adopted name 'Pahari Group' in the Indo-Aryan speeches spread along the Himalayan region from Bhadrawah in the west to Nepal in the east.

(1) Eastern Pahari: It consists of Nepali.

(2) Central Pahari: It includes 1. Kumauni, 2. Garhwali.

(3) Western Pahari: It includes 1. Jaunsari; 2. Sirmauri; 3. Baghati; 4. Kiunthali; 5. Handuri; 6. Siraji; 7. Soracholi; 8. Bashahri; 9. Siraji-InnerSiraji; 10. Sodochi; 11. Kului; 12. Mandi; 13. 
Mandeali; 14. Suketi; 15. Chameali; 16. Bharmauri/ Gaddi; 17. Churahi; 18. Pangwali; 19. Bhalesi; 20. Padari; 21. Pahari-Unspecified.

The unspecified Indo-Aryan tongues, Old Middle-Indo-Aryan languages and Mother Tongue with unspecified family affiliation are listed below:

II. Unspecified Indo-Aryan Tongues:

1. Mahasu Pahari; 2. Tharu; 3. Kewati

III Old Middle-Indo-Aryan Languages:

1. Ardhamagadhi; 2. Pali; 3. Prakrit; 4. Sanskrit

IV. Mother Tongue with Unspecified Family Affiliation:

1. Kisan; 2. English

Languages of the Indo-Aryan family are concentrated in the plains of India. The domain of Indo-Aryan languages, however, extends over the peninsular plateau also, reaching as far as the Konkan coast. The central part of this region has Hindi as the principal language. It is spoken by the majority of people in India. Hindi is spoken in Uttar Pradesh, Madhya Pradesh, Bihar, Rajasthan, Haryana, Himachal Pradesh and the Union Territory of Delhi. Urdu is closely akin to Hindi and is widely distributed in this belt. The speeches belonging to the north-western groups, such as Sindhi is mainly concentrated in Western India. Marathi is the most important language of the southern group of the Indo-Aryan family. The languages of the eastern group, such as Oriya, Bengali andAssamese are spoken in the Eastern India. The languages of the central group are confined to Punjab, Rajasthan and Gujarat. The Himalayan and the sub-Himalayan areas are inhabited by the speakers of the various forms of Pahari speeches.

\subsection{Linguistic Regions}

The geographical distribution of the major languages in India nearly fits into a scheme of linguistic regions. Based on the principle of numerical strength about a dozen major languages constitute the principal linguistic regions. However, the tribal languages do not fit into this scheme of regions as the tribal groups are concentrated in enclaves in central, eastern and north-eastern parts of the country. The regional mosaic of the tribal languages is highly complex and does not lend itself to a simplified scheme of regions.

Broadly speaking the principal languages of India constitutes the following linguistic regions:
1. Kashmiri, 2. Punjabi, 3. Hindi/Urdu, 4. Bengali, 5. Assamese, 6. Oriya, 7. Gujarati, 8. Marathi, 9. Kannada, 10. Telugu, 11. Tamil and 12. Malayalam.

The tribal languages are so distributed that either they have their own small clusters or they overlap the regions of major languages. In the north-east, however, the tribal speeches such as those of minor groups in Arunachal have almost knife-edged boundaries of their own.

The twelve linguistic regions identified above, generally correspond with the states of Indian Union. But the state boundaries do not always correspond with the linguistic boundaries. In fact the linguistic boundary in itself is not a line, it is one of transition over which one language gradually loses its dominance and gives way to the other.

\subsection{Languages Specified in Schedule VIII to the Constitution of India}

The Schedule VIII recognizes fifteen languages in India; there are 95.37 per cent speakers of these languages in the total Indian population (Part ' $\mathrm{A}$ '). The remaining 4.63 per cent is accounted for by others (Part ' $\mathrm{B}$ '). The identifiable mother tongues at all India level have been grouped under the relevant language (s) (Census of India 1971) as given below:

Part 'A'

1. Assamese

2. Bengali: Chakma; Haijong/Hajong; Malpaharia; Rajbansi

3. Gujarati: Saurashtra

4. Hindi: Awadhi, Baghelkhandi, BagriRajasthani; Banjari; Bhadrawahi; Bharmauri/ Gaddi; Bhojpuri; Braj Bhasha; Budelkhandi; Chambeali; Chattisgarhi; Churahi; Dhundhari; Garhwali; Gojri; Harauti; Haryanvi; Hindustani; Jaipuri; Jaunsari; Kangri; Khairari; Kortha/ Khatta; Kulvi; Kumauni; Kurmali; Thar; Lamani/ Lambadi; Lodhi; Madhesi; Magadhi/Maghi; Maithili, Malvi; Mandeali; Marwari; Mewari; Mewati; Nagpuria Nimadi; Pahari (It is a combination of various speeches spoken over long stretches of areas, where the speakers preferred to give a general name as Pahari); Panchpargania; Pawari/Powari; Rajasthani; Sadan/Sadri; Sirmauri; Sondwari; Surgujia.
5. Kannada: Badaga
6. Kashmiri: Kishtwari, Siraji
7. Malayalam: Yerava

8. Marathi: Karami 
9. Oriya: Bhatri, Relli

10. Punjabi: Bagri, Bilaspuri/Kahluri

11. Sanskrit

12. Sindhi: Kachchhi

13. Tamil: Kaikadi; Yerukala/Yerukula

14. Telugu: Vadari

15. Urdu

Part ' $B$ '

Adi: Adi Gallong/Gallong; Adi Minyong/

Minyong

Angami: Chakra/Chokri

Bhili/Bhilodi Barel; Bhilai; Chodhari; Dhodia;

Gamti/Gavit; Garasia; Kokna/Kokni/Kukna;

Mawchi; Paradhi; Pawri; Tadavi; Vasava; Varli;

Wagdi

Bodo/Boro: Kachari; Mech

Gondi: Dorli; Maria; Muria

Khandeshi: Ahirani; Dangi; Gujari-Khandeshi

Khasi: Pnar/Synteng; War

Konda: Kodo

Korku: Muwasi

Lahnda: Multani, Punchhi

Munda: Kol

Naga: Zeliang

Tagin

Nissi/Dafla: Apatani; Bangni; Nishang;

Paril: Dhurwa

Santali: Karmali; Mahili

Tripuri: Jamatia; Reang

A few studies are available in which researchers have identified and attempted to distinguish the people of Indian region to study the biological diversity and that are almost similar to that reported by Bhasin, 1988; Bhasin et al., 1992, 1994; Bhasin and Walter 2001)

\section{REFERENCES}

Abe K 1985. An effort at racial classification of the people in South India and Sri Lanka. Principal component analysis on 23 ethnic groups. Juntendo Univ Bull Lett Sci, 28: 12-28.

Abe K, Tamura H 1983. An effort at racial classification of the people in South India and Sri Lanka. Somatometric anylysis on 23 ethnic groups. Juntendo Univ Bull Lett Sci, 26: 37-49.

Allchin B, Allchin R 1983. The Rise of Civilization in India and Pakistan. New Delhi: Select book Service Syndicate.

Bamshad M, Watkins S, Dixion ME, Jorde LB, Rao BB, Naidu JM et al. 1998: Female gene flow stratifies Hindu castes. Nature, 395: 651-652.

Bamshad M, Kivisild T, Watkins, WS, Dixon ME, Ricker, $\mathrm{CE}$, Rao BB et al. 2001. Genetic evidence on the origins of Indian caste populations. Genome Res, 11: 994-1004.

Bamshad M, Wooding S, Salisbury BA, Stephens JC. 2004.
Deconstructing the relationship between genetics and race. Nat Rev Genet, 5(8): 598-609.

Banerjee AR 1959. Hair, pp 37-49. In: A Physical Survey of the Kadar of Kerala. Memoir No. 6. S.S. Sarkar, G Ray, MR Chakravartti, AR Banerjee, P. Bhattacharjee. Calcutta: Anthropological Survey of India.

Basu A, Mukherjee N, Roy S, Sengupta S, Banerjee S, Chakraborty M, et al. 2003. Ethnic India: A genomic view, with special reference to peopling and structure. Genome Res, 13: 2277-2290.

Bhasin MK 1988 Biology of the Peoples of Indian Region (Bangladesh, Bhutan, India, Maldives, Nepal, Pakistan, Sri Lanka). A Classified and Comprehensive Bibliography. Delhi: Kamla-Raj Enterprises.

Bhasin MK, Nag Shampa 1994. Incidence of consanguinity and its effects on fertility, mortality and morbidity in Indian Region: A Reappraisal. Pp. 161124. In: People, Health and Disease: The Indian Scenario. Veena Bhasin (Ed.). Delhi: Kamla-Raj Enterprises.

Bhasin MK, Walter H, Danker-Hopfe H 1992. The Distribution of Genetical, Morphological and Behavioural Traits among the People of Indian Region (Bangladesh, Bhutan, India, Maldives, Nepal, Pakistan, Sri Lanka). Delhi: Kamla-Raj Enterprises.

Bhasin MK, Walter H, Danker-Hopfe H 1994. People of India: An Investigation of Biological Variability in Ecological, Ethno-economic and Linguistic Groups. Delhi: Kamla-Raj Enterprises.

Bhasin MK, Walter H 2001. Genetics of Castes and Tribes of India. Delhi: Kamla-Raj Enterprises.

Bhattacharyya NP, Basu P, Das M, Pramanik S, Banerjee R, Rao B, et al. 1999. Negligible male gene flow across ethnic boundaries in India, revealed by analysis of Y-chromosomal DNA polymorphisms. Genome Res, 9: 711-719.

Biasutti R 1959. Razze e popolidella terra. 3. ed. Torino.

Birdsell JB 1972. Human Evolution. Chicago: Rand McNally.

Blunt EAH 1969. The Caste System of Northern India (1931). Reprinted, Delhi: S. Chand.

Bowles GT 1977. The People of Asia. London: Weidenfeld and Nicholson.

Boyd WC 1963. Genetics and the human race. Science, 140: 1057

Büchi EC 1968. Rassengeschichte des indopakistanischen Subkontinents. pp. 109-184. In : Rassengeschichte der Menschheit, 1. Lieferung. K Saller (Hrg.). München-Wien: Oldenbourg.

Cammiade LA, Burkitt MC 1930. Fresh light on the stone ages in South-East India. Antiquity, IV: $327-$ 339.

Cann RL 2001. Genetics clues to dispersal in human populations: Retracing the past from the present. Science, 291(5509): 1742-1748.

Cavalli-Sforza LL 2005. The human genome diversity project: Past, present and future. Nat Rev Genet, 6: 333-340.

Cavalli-Sforza LL, Bodmer WF 1971. The Genetics of Human Populations. San Francisco: Freeman.

Cavalli-Sforza LL, Feldman MW 2003. The application of molecular genetic approaches to the study of 
human evolution. Nat Genet, 33 Suppl: 266-275.

Cavalli-Sforza LL, Piazza A, Menozzi P, Mountain J 1988. The reconstruction of human evolution: Bringing together genetic, archaeological and linguistic data. Proc Natl Acad Sci USA, 85: 60026006.

Cavalli-Sforza LL, Piazza A, Menozzi P 1994. The History and Geography of Human Genes. Princeton, New Jersey: Princeton University Press.

Census of India 1971. Series 1 India Paper 2 of 1972 Religion. New Delhi: The Registrar General \& Census Commissioner, India (1972).

Census of India 1971. Under Census Centenary: Language Handbook on Mother Tongues in Census. New Delhi: Office of the Registrar General, India, Ministry of Home Affairs (1972).

Census of India 1971. Series 1-India. Part V-A(I) Special Tables for Scheduled Castes. New Delhi: The Registrar General \& Census Commissioner, India (1979).

Census of India 1971. Series 1-India. Part V-A (ii) Special Tables for Scheduled Tribes. New Delhi: The Registrar General \& Census Commissioner, India (1981).

Census of India 1981, Series-1 India. Paper 2 of 1984. General Population and Population of Scheduled Castes and Scheduled Tribes. New Delhi: The Registrar General \& Census Commissioner, India (1984).

Census of India 1981. Series-1 India. Paper 3 of 1984, Household Population by Religion of Head of Household. New Delhi: The Registrar General \& Census Commissioner, India (1985).

Census of India 1991. Series-1, Paper 1 of 1991. Provisional Population Totals. New Delhi: Office of the Registrar General \& Census Commissioner, India (1991).

Chakravartti MR 1968. Consanguinity in India. Morph Anthrop, 60: 170-183.

Chanda R 1978. The Indo Aryan Races : A Study of the Origin of Indo-Aryan People and Institutions (1916). New Delhi: Cosmo Publications, Reprinted.

Collins FS, Green ED, Guttamacher AE, Guyer MS 2003. A vision for the future genomics research. Nature, 422: $835-847$.

Coon CS 1965, 1970. The Living Races of Man. New York: Knopf.

Cordaux R, Aunger G, Bentley G, Nazidze I, Sirajuddin SM, Stoneking M 2004. Independent orgins of Indian caste and tribal paternal lineages. Curr Biol, 14: $231-235$

Dixon RB 1923. The Racial History of Man. New York: Chas Scribner's Sons.

Dronamraju KR 1963. Genetic studies of the Andhra Pradesh population. pp. 154-159. In: The Genetics of Migrant and Isolate Populations. E Goldschmidt (Ed.). Williams and Wilkins. Proc. Conf. Hum. Pop. Genet, Israel.

Dronamraju KR, Meera Khan P 1963a. A study of Andhra marriages: Consanguinity, caste, illiteracy and bridal age. Acta Genet Stat Med, 13: 21-29.

Dronamraju KR, Meera Khan P 1963b. Inbreeding in Andhra Pradesh (1961). pp. 126-127. Proc 2nd Int Cong Hum Genet, Rome.

Dutta R, Reddy BM, Chattopadhyay P, Kashyap VK,
Sun G, Deka R 2002. Patterns of genetic diversity at the nine forensically approved STR loci in the Indian populations. Hum Biol, 74: 33-49.

Eickstedt E Frh v 1934. Rassenkunde und Rassengeschichte der Menschheit. Stuttgart: Ferdinand Enke Verlag.

Eickstedt E Frh v 1939. Introduction, Vol. II. The Travancore Tribes and Castes. Trivandrum.

Eickstedt E Frh v 1952. Rassentypen und Typendynamik von Asien. pp. 147-166. In: Historia Mundi. Volume 1. F. Valjavec (Ed.). München.

Endicott P, Gilbert MTP, Stringer C, Lalueza-Fox C, Willerslev E, Hansen AJ, Cooper A 2003. The genetic origins of the Andaman Islanders. Am J Hum Genet, 72: 178-184.

Fairservis WA 1971. The Roots of Ancient India. New York: Macmillan.

Gazetteer of India 1973. Volume I - Country and People. Ministry of Education and Social Welfare, Government of India, New Delhi (First printed 1965, Reprinted)

Giuffrida-Ruggeri V 1921. First Outlines of a Systematic Anthropology of Asia. Calcutta.

Grierson Sir George 1903-1928. Linguistic Survey of India: Volume I-XI, Calcutta: Central Publication Branch, GOI.

Guha BS 1928. Negrito racial strain in India. Nature (Lond.), 121: 793 .

Guha BS 1929. Negrito racial strain in India. Nature (Lond.), 122: 942.

Guha BS 1935. Racial affinities of the people of India. Census of India, 1931. Report,Vol. 1, Pt. III Ethnographical. Sec. A. Government of India, Simla.

Guha BS 1937. An outline of racial ethnology of India, pp. 125-139. In: An Outline of the Field Sciences in India. SL Hora (Ed.). Calcutta.

Guha BS 1941, 1944. The Racial Elements in Indian Populations. Oxford Pamphlet in Indian Affair.

Ghurye GS 1969. Caste and Race of India. Bombay: Popular Prakashan, Bombay.

Haddon AC 1925. Races of Man and Their Distribution. New York: Macmillan.

Hooten EA 1930. The Indians of Pucos Pueblo. New Haven, Conn.

Hutton JH 1933. Census of India. Vol. I. Report 1931, Delhi.

Jorde LB, Wooding SP 2004. Genetic variation, classigication and 'race'. Nat Genet, 36: S28-33.

Kapadia KM 1982. Marriage and Family in India. Calcutta: Oxford University Press, 3rd Edition.

Karve I 1968. Kinship Organization in India. Bombay: Asia Publishing House.

Kashyap VK, Sitalaximi T, Sarkar BN, Trivedi R 2003. Molecular relatedness of the aboriginal groups of Andaman and Nicobar Islands with similar ethnic populations. Int J Hum Genet, 3: 5-11.

Keith A 1936. Review of BS Guha's the racial affinities of the peoples of India. Man, 36: 28-30.

Kennedy KAR 2000. God-Apes and Fossil Men. Paleoanthropology of South Asia. Ann Arbor: The University of Michigan Press.

Kennedy KAR, Caldwell PC 1984. South Asian prehistoric human skeletal remains and burial practices. pp. 159-197. In : The People of South Asia, The Biological Anthropology of India, Pakistan and Nepal. 
JR Lukacs (Ed.). New York: Plenum Press.

Kennedy KAR, Sonakia A, Chiment J, Verma KK 1991. Is the Narmada hominid an Indian Homo erectus? Am J Phys Anthrop, 86: 475-496.

Kirk RL 1976. Serum protein and enzyme markers as indicators of population affinities in Australia and the Western Pacific. pp. 329-346. In: The Origins of the Australians. RL Kirk, AG Thorne (Eds.). Human Biology Series No.6. Australian Institute of Aboriginal Studies, New Jersey: Canberra Humanities Press, Inc.

Kivisild T, Kaldma K, Metspalu M, Parik J, Papiha S, Villems R 2000. The place of the Indian mitochondrial DNA variants in the global network of maternal lineages and the peopling of the old world. pp. 135-152. In: Genomic Diversity. Applications in Human Population Genetics. SS Papiha, R Deka, R Chakraborty (Eds.), New York: Kluwer/Academic Publications.

Kivisild T, Rootsi S, Metspalu M, Mastana S, Aldma K, Parik J, et al. 2003. The genetic heritage of the earliest settlers persists both in Indian tribal and caste populations. Am J Hum Genet, 72(2): 3131332

Lahr M, Foley R 1994. Multiple disperdals and modern human origins. Evolutionary Anthropology, 3: 4860.

Lahr M, Foley R 1998. Towards a theory of modern human origins: Geography demography and diversity in recent human evolution. Am J Phys Anthrop, 27: $137-176$.

Lakshmi N, Demarchi DA, Veerraju P, Rao TV 2002. Population structure and genetic differentiation among the substructured Vysya caste population in comparison to the other populations of Andhra Pradesh, India. Ann Hum Biol, 29(5): 538-549.

Lasker GW 1967. The 'New' Physical Anthropology seen in retrospect and prospect. pp. 3-17. In: Human Evolution, Readings in Physical Anthropology. Noel Korn, Fred Thompson (Eds.). New York: Holt, Rinehart and Winston Inc.

Long JC, Chakravarti A, Boehm CD, Antonarakis S, Kazazian HH 1990. Phylogeny of human betaglobin haplotypes and its implications for recent human evolution. Am J Phys Anthrop, 81: 113130

Lumley H, Sonakia A 1985. Contexte stratigraphique et archaéologique de l'homme de la Narmada, Hathnora, Madhya Pradesh Inde. L' Anthropologie, 89: 3-13.

Lumley MA, Sonakia A 1985. Première décourverte d'un Homo erectus sur le continent Indian a Hathnore dans la moyenne vallée de la Narmada. $L$ ' Anthropologie, 89: 13-61.

Malhotra KC 1976. Inbreeding among 22 semi-nomadic Dhangar Castes of Maharashtra: A preliminary report. ISI Tech. Report. No. Anthrop /4/76.

Malhotra KC 1978. Morphological composition of the people of India. J Hum Evol, 7: 45-53.

Misra VN 1962. Problems of terminology in Indian Prehistory. East Anthrop, 15: 113-124.

Mountain JL, Hebert JM, Bhattacharyya S, Undehill P A, Ottolenghi C, Gadgil M, Cavalli-Sforza LL 1995. Demographic history of India and mtDNA-sequence diversity. Am J Hum Genet, 56: 979-992.
Murhekar KM, Murhekar MV, Mukherjee MB, Gorakshakar AC, et al. 2001. Red cell genetic abnormalities, $\beta$ - globin gene haplotypes, and APOB polymorphism in the Great Aqndamanese, a primitive Negrito tribe of Andaman and Nicobar Islands, India. Hum Biol, 73: 739-744.

Mourant AE 1983. Blood Relations, Blood Groups and Anthropology. Oxford: Oxford University Press.

Murty JS, Jamil T 1972. Inbreeding load in the newborn of Hyderabad. Acta Genet Med Gemell, 21: $327-$ 331.

Nei M, Roychoudhury AK 1982. Genetic relationship and evolution of human races. Volume 14: 1-59. In: Evolutionary Biology, Max K Hecht, Bruce Wallace, GT Prance (Eds.). New York: Plenum Publishing Corporation.

Palanicharmy MG, Sun C, Agrawal S, Bandelt H J, Kong QP, Kahn F, et al. 2004. Phylogeny of mitochondrial DNA macrohaplogroup $\mathrm{N}$ in India based on complete sequencing: Implications for the peopling of South Asia. Am J Hum Genet, 75(6): 966-978.

Pietrusewsky M 1990. Craniofacial variation in Australasian and Pacific Populations. Am J Phys Anthrop, 82: 319-340.

Piggot S 1952. Prehistoric India. Harmondsworth, Middlesex: Penguin Books.

Pingle U 1975. Comparative analysis of mating systems and marriage distance patterns between five tribal groups of Utnur Taluka, Adilabad District of Andhra Pradesh. Proc. 2nd Annual Conf Ind Soc Hum Genet, Calcutta.

Quintana-Murei L, Krausz C, Zerjal T, Sayar SH, Hammer, MF, Mehdi SO et al. 2001. Y-chromosome lineages trace diffusion of people and languages in southwestern Asia. Am J Hum Genet, 68: 537-542.

Rakshit HK 1965. The Mongolian element in Indian populations. Real and alleged. Anthropos, 60: 4964.

Rao AP, Mukherjee DP 1975. Consanguinity and inbreeding effects on fertility, mortality and morbidity in a small population of Tirupati. Proc 2nd Conf Ind Soc Hum Genet, Calcutta.

Reddy PC 1983. Consanguinity and marriage distance among the Mala populations of Chittoor district, Andhra Pradesh. Coll Anthrop, 7: 43-48.

Renfrew C 1987. Archaeology and Language: The Puzzle of Indo-European Origins. New York: Cambridge University Press.

Renfrew C 1989. The origins of Indo-European languages. Sci Am, 261: 82-90.Cavalli-Sforza LL, Piazza A, Menozzi P, Mountain, J. 1988. The reconstruction of human evolution: Bringing together genetic, archaeological and linguistic data. Proc Natl Acad Sci USA, 85: 6002-6006.

Renfrew C 1996. Languages families and the spread of farming, pp. 70-92. In: The Origins and Spread of Agriculture and Pastoralism in Eurasior DR Harris (Ed.). Washington DC: Smillsonian Institution Press.

Risley H Sir 1969. The People of India. (1915). Delhi: Orient Book Reprint Corporation, Reprinted.

Roy S C 1938. Caste, race and religion in India. Man in India, 14: 39-63, 75-220, 271-311 (1934); 17: 147-176, 212-254 (1937); 18: 85-105.

Roychoudhury AK 1976. Inbreeding in Indian populations. Trans Bose Res Inst, 39: 65-76. 
Roychoudhury AK 1984. Genetic relationsip between Indian tribes and Australian Aboriginals. Hum Hered, 34: 314-322.

Roychoudhury S, Roy S, Dey B, Chakraborty M, Roy M, Roy B, et al. 2000. Fundamental genomic unity of ethnic India is revealed by analysis of mitochondrial DNA. Curr Sci, 79: 1182-92.

Ruhlen, M.: A guide to the World's languages. Edward Arnold, London Sheratt A. (Ed.). The Cambridge Encyclopedia of Archaeology (1991).

Saha N, Kirk RL, Shanbhag S, Joshi SH, Bhatia HM 1974. Genetic studies among the Kadar in Kerala. Hum Hered, 24: 198-218.

Sanghvi LD 1966. Inbreeding in India. Eugen Quart, 13: $591-601$

Sanghvi LD 1976. Comparative genetic studies between some groups of Australian Aboriginals and certain tribal peoples of India pp. 401-414. In: The Origins of the Australians. RL Kirk, AG Thorne (Eds.). Human Biology Series No. 6, Australian Institute of Aboriginal Studies, Canberra, New Jersey: Humanities Press Inc.

Sanghvi LD, Varde DS, Master HR 1956. Frequency of consanguineous marriages in twelve endogamous groups in Bombay. Acta Genet Stat Med, 6: 41-49.

Sankalia HD 1962. Indian Archaeology Today. Bombay: Asia Publishing House.

Sankalia HD 1973. Pre-histroic and proto-historic periods. pp. 3-41. In: The Gazetteer of India. Volume II. History and Culture. Publications Division, Ministry of Information and Broadcasting, Government of India, New Delhi.

Sankalia HD 1979. Indian Archaeology Today. Delhi: Ajanta Publications.

Sarkar SS 1954. The Aboriginal Races of India. Calcutta: Bookland Ltd.

Sarkar SS 1958. Race and race movements in India. In: The Cultural Heritage of India, Calcutta I: 17-32.

Sarkar SS 1972. Ancient Races of the Deccan. New Delhi: Munshiram Manohar Lal.

Sarkar SS, Ray G, Bhattacharjee P, Banerjee AR 1959. The Kadar of Kerala. Man in India, 39: 235-238.

Sastri KAN, Srinivasachari G 1980. Advanced History of India. New Delhi: Allied Publishers Pvt. Ltd. 2nd Edition.

Sastri N 1966. A History of South India. Delhi.

Schurr TG, Wallace DC 2002. Mitochondrial DNA diversity in Southeast Asian populations. Hum Biol, 74: 431-452.

Sen DK 1967. Racial studies in India. J Ind Anthrop Soc, 2: $1-18$.
Sewell RBS, Guha BS 1929. Reports on the bones excavated at Nal. Mem Archaeol Surv India, 35: 56-86.

Simmons RT 1976. The biological origin of Australian Aboriginals: An examination of blood group gene frequencies for possible evidence in populations from Australia to Eurasia. pp. 307-328. In: The Origins of the Australians. RL Kirk, AG Thorne (Eds.). Human Biology Series No. 6. Australian Institute of Aboriginal Studies, Canberra, New Jersey: Humanities Press Inc.

Sonakia A 1985a. Skull cap of an early man from the Narmada valley alluviuam (Pleistocene) of Central India. Am Anthrop, 87: 612-616.

Thangaraj K, Singh L, Reddy A G, Rao VR, Sehgal SC, Undehill PA, Pierson M, Frame IG, Hagelberg E 2003. Genetic affinities of the Andaman Islanders, a vanishing human population. Curr Boil, 13(2): 86-93.

Tishkoff SA, Kidd KK 2004. Implications of biogeography of human populations for 'race' and medicine. Nat Genet, 36: S21-27.

Turner II CG 2004. Major features of sundadonty and sinodonty, including suggestions about East Asian microevolution, population history, and late pleistocene relationships with Australian aboriginals. Am J Phys Anthrop, 82: 295-317.

Underhill PA, Passarino G, Lin AA, Marzuki S, Oefner PJ, Cavalli-Sforza LL et al. 2001. The phylogeography of Y chromosome binary haplotypes and the origins of modern human populations. Ann Hum Genet, 65: 43-62.

Veerraju P. 1973. Inbreeding in coastal Andhra Pradesh. pp. 309-318. In: Proceedings of the International Symposium on Human Genetics (1971). Andhra University, Waltair. MR Chakravartti (Ed.). Andhra University Press, Andhra Pradesh.

Waddel LA 1901. The Tribes of Brahmaputra Valley. Delhi: Sanskaran Prakashak.

Walter H, Danker-Hopfe H, Bhasin MK 1991. Anthropologie Indiens. Untersuchungen zur genetischen Variabilität der Bevölkerung Indiens mit besonderer Berücksi-chtigung ihrer, regionalen, ethnosozialen und sparachlichen Gliedrung. New York, Stuattgart: Gustav Fischer Verlag.

Wooding S, Ostler C, Ravi Prasad RV, Watkins S, Sung S, Bamshad M, Jorde LB 2003. Directional migration in the Hidu castes: Inferences from mitochondrial, autosomal and Y-chromosomal data. Hum Genet, 115: $221-229$. 